\title{
Fluid Geochemistry of High-Temperature Hydrothermal Fields in the Okinawa Trough
}

\author{
Shinsuke Kawagucci
}

\begin{abstract}
This review compiles fluid chemistries of the six known high-temperature hydrothermal fields in the Okinawa Trough (OT) and compares them to global representative fields with various tectonic/geologic backgrounds. The comparisons indicate that the chemical characteristics of the OT hydrothermal fluids are explained by linkages between (1) shallow water depth that constrains the maximum fluid temperature, (2) back-arc tectonic setting that introduces magmatic volatiles into the fluid, (3) probable silicic rock-based fluidmineral interaction at the hydrothermal reaction zone, and (4) seafloor sediment around the vents that provides both compounds derived from sedimentary organic matter and biogenic compounds, such as methane, produced by microbial ecosystems in the sedimentary environment.

To explain the highly diverse gas compositions and stable isotope ratios of methane among the OT hydrothermal fields, "fluid-sediment interaction" has been further classified into several types with respect to processes (microbial or chemical) and stages of subseafloor fluid circulation (recharge or discharge). This concept, called the Microbial Methanogenesis at Recharge stage (MMR) model, enables us not only to deduce the geochemical origins of the hydrothermal fluid $\mathrm{CH}_{4}$ in each OT field but also to estimate the geographical distribution of hydrothermal fluid circulation via a two-dimension schematic illustration. The model, which links the fluid geochemistry with the subseafloor fluid migration path, will serve as a base for future studies also for any subseafloor geofluid systems that include hydrothermal systems, subseafloor methane hydrate, and seismogenic fault zone.
\end{abstract}

\section{Keywords}

High-temperature hydrothermal fluid geochemistry • Inter-field comparison • Okinawa trough • Origin of methane

S. Kawagucci $(\bowtie)$

Institute of Biogeosciences (Biogeos), Japan Agency for Marine-Earth Science and Technology (JAMSTEC), 2-15 Natsushima-cho,

Yokosuka, Kanagawa 237-0061, Japan

Precambrian Ecosystem Laboratory (PEL), Japan Agency for MarineEarth Science and Technology (JAMSTEC), 2-15 Natsushima-cho, Yokosuka, Kanagawa 237-0061, Japan

Submarine Resources Research Project (SRRP), Japan Agency for Marine-Earth Science and Technology (JAMSTEC), 2-15 Natsushimacho, Yokosuka, Kanagawa 237-0061, Japan

e-mail:kawagucci@jamstec.go.jp

\subsection{Introduction}

Active hydrothermal systems in the Okinawa Trough (OT) are representative of one of the four TAIGAs, i.e., the 'TAIGA of Methane' (Urabe et al. Chap. 1). Numerous cruises for more than two decades have investigated the hydrothermal activities and fluid geochemistry of hightemperature hydrothermal fields within the OT, such as Minami-Ensei (Chiba et al. 1993; Kawagucci et al. 2013a), Iheya North (Nakagawa et al. 2005; Kawagucci et al. 2011, 
2013b), Jade (Sakai et al. 1990a, 1990b; Ishibashi et al. 1995), Hakurei (Ishibashi et al. 2014), Hatoma (Nakano et al. 2001; Saegusa et al. 2006; Kawagucci et al. 2010b; Toki et al., in preparation), and Daiyon-Yonaguni (Yonaguni IV) (Kishida et al. 2004; Konno et al. 2006; Suzuki et al. 2008). The most notable characteristics of the fluid chemistry of the OT hydrothermal fields are abundant millimolar levels of $\mathrm{CH}_{4}$ (Fig. 30.1 and Table 30.1). This is why the OT hydrothermal systems are representative of the 'TAIGA of Methane.'

The chemical characteristics of venting hydrothermal fluid are primarily constrained by high-temperature fluidrock interactions at deep hydrothermal reaction zones (Seewald and Seyfried 1990; Seyfried et al. 2003; German and von Damm 2003). Phase separation and subsequent phase segregation occurring at deep high-temperature region also affect the chemistry of the venting fluid (Gamo 1995). Furthermore, certain microbial and chemical effects on hydrothermal chemistry have been identified in the branched low-temperature diffusing fluid in the discharge stage (Butterfield et al. 2004; von Damm and Lilley 2004; Toki et al. 2008). These key processes, however, have been hypothesized to occur in the high-temperature hydrothermal reaction zones and during the discharge stage, not in the fluid recharge stage, where cool seawater penetrates into the subsurface and its chemistry changes with increasing temperature via relevant (bio)geochemical processes.

Recently, I and my colleagues have claimed that chemical and biological processes occurring in the recharge stage significantly affect the chemical composition of the venting fluid in the case that the product is inert under the conditions of the high-temperature hydrothermal reaction zone, such as methane (Kawagucci et al. 2011, 2013a). From this point of view, we have considered Microbial Methanogenesis at Recharge stage (MMR) in hydrothermal circulation as a possible predominant source of $\mathrm{CH}_{4}$ in the high-temperature venting fluid, and refer to the concept as the 'MMR model' (Kawagucci et al. 2011). The MMR model is relevant particularly in a sediment-associated hydrothermal system, where the recharge stage of hydrothermal fluid circulation is expected to include an organic-rich sedimentary environment that promotes the widespread occurrence of functionally active microbial communities and impacts on fluid chemistry. Although the characteristic fluid chemistry in sediment-associated hydrothermal systems has occasionally been explained by equivocal 'fluid-sediment interaction', the MMR model argues that "fluid-sediment interaction" has been further classified into three types with respect to processes (microbial or chemical) and stages of subseafloor fluid circulation (recharge or discharge) (Kawagucci et al. 2013a).

In this chapter, I attempt to discover how and where the 'TAIGA of Methane' forms mainly based on fluid chemistry, following the recently proposed MMR model (Kawagucci et al. 2011, 2013a). For this purpose, general characteristics of the hydrothermal fluid chemistry of the OT fields are reviewed at first and then compared with those of other hydrothermal systems in Sect. 30.2. After assessing the utility of geochemical tracers to deduce the origin of hydrothermal fluid methane in Sect. 30.3, I discuss the geochemical origins of $\mathrm{CH}_{4}$ dissolved in hydrothermal fluid in each OT field and their relevance with the geological setting and geographical distribution of hydrothermal fluid circulation in Sect. 30.4.

\subsection{Major Fluid Chemistry}

\subsubsection{General View of the OT Hydrothermal Fluids}

The OT hydrothermal fluids show significant enrichment of not only $\mathrm{CH}_{4}$ but also of some other components (e.g., $\mathrm{CO}_{2}$, $\mathrm{K}, \mathrm{NH}_{4}$, etc.) compared to hydrothermal fluids collected from sediment-starved Mid-Ocean Ridge (MOR) fields. Pioneering works (Sakai et al 1990a, 1990b; Gamo et al. 1991; You et al. 1994; Ishibashi et al. 1995) noted that the distinctive chemistry of the OT hydrothermal fluids is linked with the organic-rich continent-derived sediment filling the OT seafloor and the volatile-rich dacitic-rhyolitic (silicic) magma beneath the OT. Moreover, relatively shallow water depths of the OT hydrothermal systems (Fig. 30.1) serve as a physical factor that induces frequent boiling (subcritical phase separation) and subsequent phase segregation (Fig. 30.2), which results in chemical compositions of the venting hydrothermal fluids that are quite different from the deep source fluid (Gamo 1995). Phase separation forces volatile species into the resulting 'vapor' phase and leaves ion species in the 'liquid' phase. The source hydrothermal fluid composition prior to the phase separation can be estimated by a simple correction using the venting fluid chlorine concentration (i.e., the ion-element/ $\mathrm{Cl}$ ratio) (Butterfield et al. 2003). Despite potential influences of multiple factors due to the geological and tectonic backgrounds of the OT, limited observations at each sediment-associated basalt-hosted MOR system and sediment-starved silicic rock-hosted arc-back-arc (ABA) system in the early 1990s inhibited the understanding of how the sediment filling the OT seafloor and volatile-rich silicic host rocks impact the OT hydrothermal fluid chemistry. Over the 35 years since the discovery of deep-sea hydrothermal activity in 1977, the current global dataset of hydrothermal fluid chemistry has enabled us to compare the fluid chemistry of the OT fields with that of hydrothermal systems of various geological and tectonic backgrounds. Field-to-field variations (inter-field variation) of fluid 

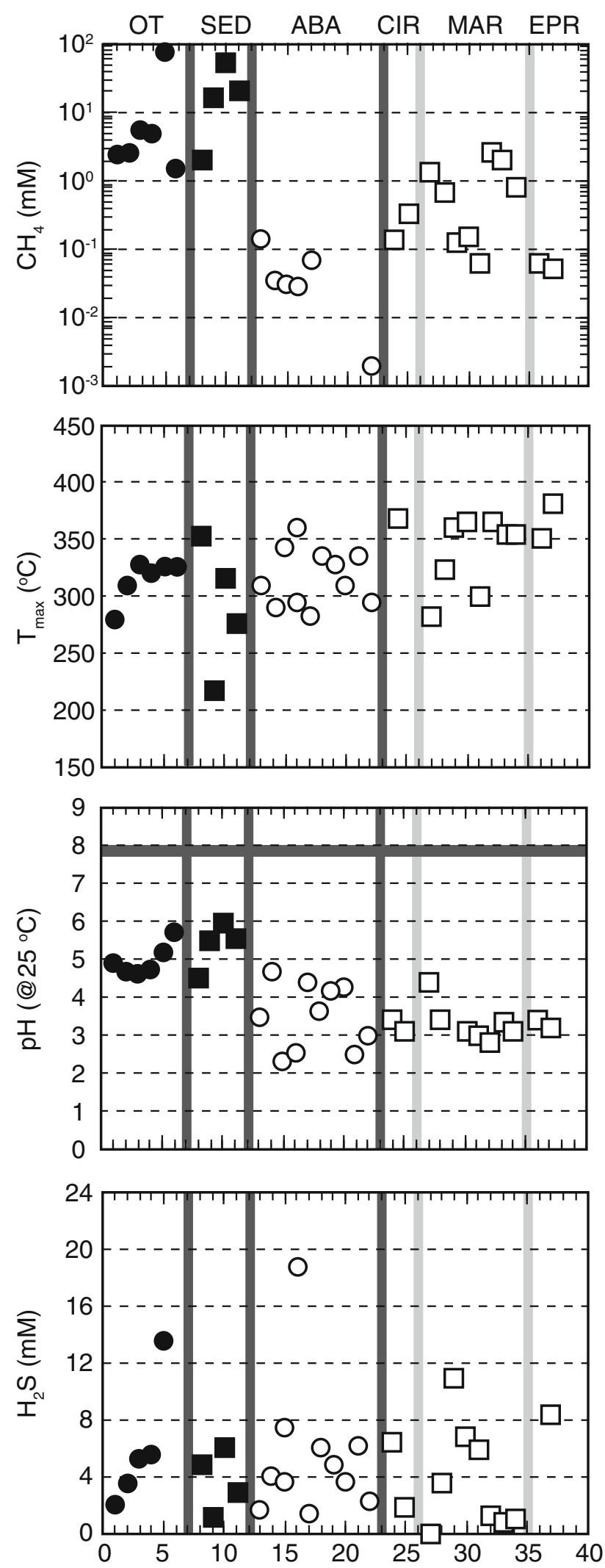

Fig. 30.1 Compilation of the physical properties and fluid chemistry of the Okinawa Trough and global hydrothermal fields. The vertical axis (methane concentration) is in logarithm scale. Horizontal axes are common for all panels and represent each hydrothermal field as follows: 1-Minami-Ensei, 2-Iheya North, 3-Hakurei, 4-Jade, 5-Hatoma, 6-Daiyon-Yonaguni, 7-vacant, 8-Endeavour, 9-Escanaba, 10Guaymas, 11-Middle Valley, 12-vacant, 13-Suiyo, 14-North Fiji, 15Roman Ruins, 16-Satanic Mills, 17-Vienna Woods, 18-Kilo Moana,
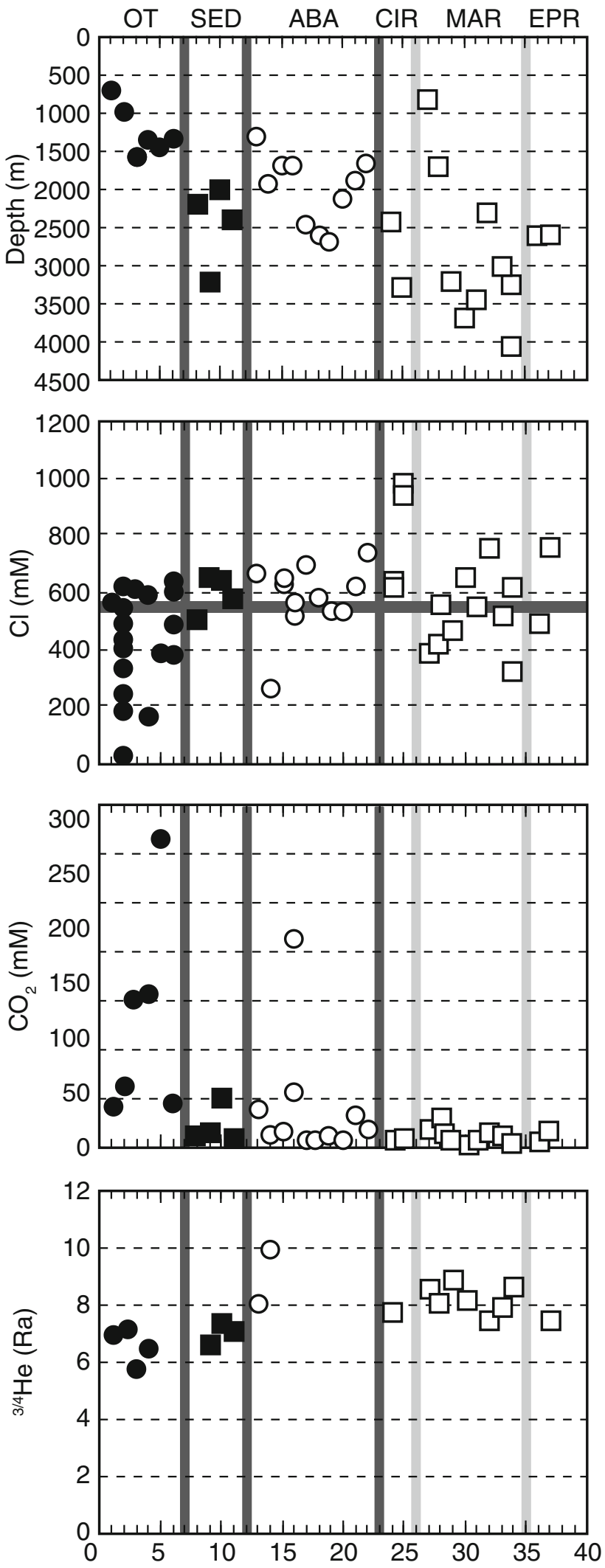

19-Tow Cam, 20-ABE, 21-Mariner, 22-Brother, 23-vacant, 24-Kairei, 25-Edmond, 26-vacanct, 27-Manez Gwen, 28-Lucky Strike, 29-Broken Spur, 30-TAG, 31-Snake Pit, 32-Rainbow, 33-Logatchev, 34-Ashadze, 35-vacant, 36-EPR21N, 37-EPR13N. Vertical dark and light gray bars separate different geological/tectonic settings. Horizontal gray bars in several panels represent seawater levels. References for this figure are presented in Sect. 30.2.2 

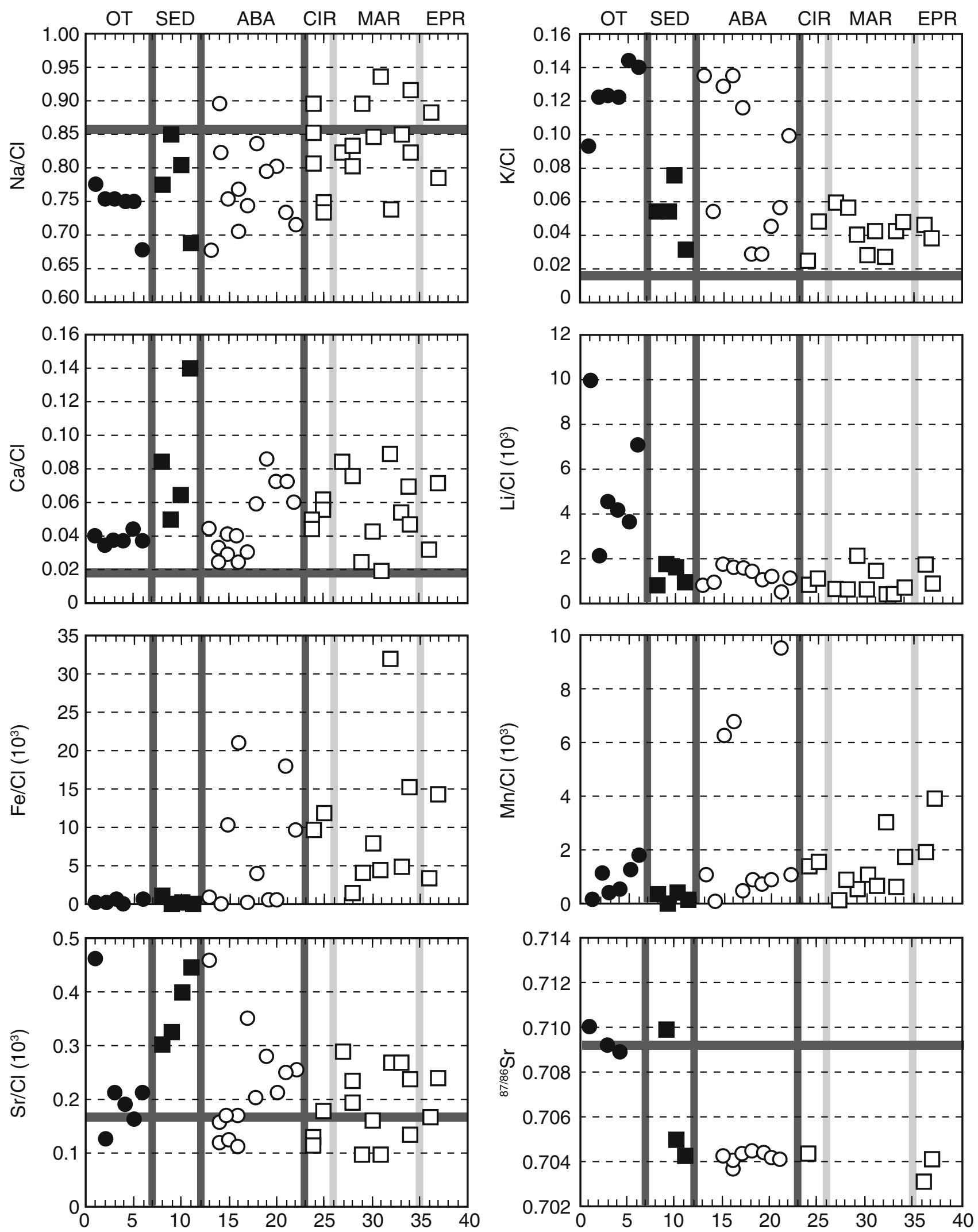

Fig. 30.1 (continued) 
Table 30.1 Fluid chemistry of the Okinawa Trough hydrothermal fields

\begin{tabular}{|c|c|c|c|c|c|c|c|c|c|c|}
\hline \multirow[b]{2}{*}{ Field vent } & \multirow[b]{2}{*}{$\begin{array}{l}\text { Minami Ensei } \\
\text { (whole) }\end{array}$} & \multicolumn{2}{|c|}{ Iheya North } & \multicolumn{3}{|l|}{ Izena Hall } & \multirow{2}{*}{$\begin{array}{l}\text { Hatoma } \\
\text { Gusuku }\end{array}$} & \multicolumn{2}{|c|}{ Daiyon-Yonaguni } & \multirow[b]{2}{*}{ Seawater } \\
\hline & & $\begin{array}{l}\text { NBC } \\
2011\end{array}$ & Variation & Jade & Hakurei & Biwako & & Lion & Variation & \\
\hline Depth (m) & 700 & 980 & & 1,350 & 1,600 & 1,525 & 1,473 & 1,360 & & \\
\hline $\mathrm{T}_{\max }\left({ }^{\circ} \mathrm{C}\right)$ & 280 & 309 & $<311$ & 320 & 326 & 104 & 325 & 325 & $<328$ & \\
\hline $\mathrm{pH}$ & 4.9 & 4.65 & $>4.65$ & 4.7 & 4.7 & 4.8 & 5.2 & 5.7 & $5.7-6.8$ & 7.8 \\
\hline Alk. (mM) & 3.3 & 1.3 & $0.2-3.3$ & 1.5 & 1.5 & & 4.7 & 0.25 & $0.25-2.95$ & 2.3 \\
\hline $\mathrm{Cl}(\mathrm{mM})$ & 562 & 599 & $16-634$ & 590 & 608 & 167 & 381 & 614 & $376-635$ & 559 \\
\hline $\mathrm{Na}(\mathrm{mM})$ & 436 & 451 & $8-479$ & 442 & 458 & 173 & 285 & 416 & $254-433$ & 480 \\
\hline $\mathrm{K}(\mathrm{mM})$ & 53 & 73 & $7-82$ & 72 & 75 & 12 & 55 & 86 & $55.3-90.1$ & 10 \\
\hline $\mathrm{Ca}(\mathrm{mM})$ & 23 & 21.1 & $0-25$ & 22 & 23 & 4.3 & 17 & 23.2 & $14.3-26.1$ & 11 \\
\hline $\mathrm{Si}(\mathrm{mM})$ & 11.1 & 11.9 & $3.1-13.8$ & 11.8 & 11.3 & 11 & 12 & 11.3 & $11.3-13.2$ & 0.18 \\
\hline $\mathrm{B}(\mathrm{mM})$ & 3.8 & 1.97 & $0.44-2.3$ & 3.2 & 3.7 & 1 & 3.3 & 3.9 & $2.93-4.31$ & 0.43 \\
\hline $\mathrm{Li}(\mathrm{mM})$ & 5.6 & 1.32 & $0.11-1.52$ & 2.5 & 2.8 & & 1.4 & 4.4 & & 0.026 \\
\hline $\mathrm{Fe}(\mu \mathrm{M})$ & 120 & 121 & $31-142$ & 31 & 445 & & 8.6 & 410 & $80-410$ & 0.001 \\
\hline $\mathrm{Mn}(\mu \mathrm{M})$ & 99 & 694 & $115-694$ & 341 & 290 & & 483 & 1,120 & $700-1,250$ & 0.003 \\
\hline $\mathrm{Ba}(\mu \mathrm{M})$ & & 31 & $9.7-44$ & 65 & 120 & & & & & 0.15 \\
\hline $\mathrm{Al}(\mu \mathrm{M})$ & 4.7 & 11.0 & & & & & & & & 0.04 \\
\hline $\mathrm{Sr}(\mu \mathrm{M})$ & 260 & 77 & & 115 & 129 & 27 & 62 & 130 & & 91 \\
\hline${ }^{87 / 86} \mathrm{Sr}$ & 0.71 & & & 0.7089 & $(0.7094)$ & & & & & 0.70918 \\
\hline $\mathrm{F}(\mu \mathrm{M})$ & & 209 & & & & & & & & 70 \\
\hline $\mathrm{Br}(\mu \mathrm{M})$ & & 952 & & & & & & & & 860 \\
\hline $\mathrm{I}(\mu \mathrm{M})$ & 30 & 44.8 & & & & & & & & 0.5 \\
\hline Mo (nM) & & & & & & & 7 & & & 107 \\
\hline $\mathrm{W}(\mathrm{nM})$ & & 320 & & & & & 123 & & & 0.07 \\
\hline $\mathrm{Zn}(\mu \mathrm{M})$ & & 94 & & & & & & & & 0.01 \\
\hline $\mathrm{Se}(\mathrm{nM})$ & & 73 & & $40-150$ & $50-100$ & & & & & 2.3 \\
\hline $\mathrm{CH}_{4}(\mathrm{mM})$ & 2.4 & 2.5 & $0.2-7.0$ & 4.9 & 6.8 & & 80 & 1.6 & $1.2-13.5$ & 0.0000001 \\
\hline $\begin{array}{l}\delta^{13} \mathrm{C}_{\mathrm{CH} 4} \\
(\% o)\end{array}$ & -25 & -54.1 & $\begin{array}{l}-58.2 \text { to } \\
-54.0\end{array}$ & -30.8 & -32.1 & & -50 & -26.9 & $\begin{array}{l}-27.3 \text { to } \\
-24.8\end{array}$ & \\
\hline$\delta \mathrm{D}_{\mathrm{CH} 4}(\% o)$ & -112 & -124 & -132 to -113 & -113 & -113 & & & & & \\
\hline $\mathrm{H}_{2}(\mathrm{mM})$ & 0.04 & 0.10 & $0.03-0.2$ & 0.06 & 1.4 & & 0.2 & 1.0 & $0.8-5.5$ & 0.0000001 \\
\hline$\delta \mathrm{D}_{\mathrm{H} 2}(\% o)$ & -420 & -394 & -430 to -394 & -381 & -379 & & -386 & & & \\
\hline $\mathrm{CO}_{2}(\mathrm{mM})$ & 42 & 63 & $27-228$ & 156 & 151 & & 315 & 47 & $22-329$ & 2.3 \\
\hline $\begin{array}{l}\delta^{13} \mathrm{C}_{\mathrm{CO} 2} \\
(\%)\end{array}$ & -5.1 & -9.6 & -10.8 to -8.8 & -6.2 & -6.2 & & -7.9 & -7.3 & -8.0 to -7.2 & -8 \\
\hline$\delta \mathrm{D}_{\mathrm{H} 2 \mathrm{O}}(\% o)$ & & -1.0 & & -0.3 & -0.6 & & & & & 0 \\
\hline $\begin{array}{l}\delta^{18} \mathrm{O}_{\mathrm{H} 2 \mathrm{O}} \\
(\% o)\end{array}$ & & +1.2 & & +1.8 & +1.6 & & & & & 0 \\
\hline $\mathrm{NH}_{4}^{+}(\mathrm{mM})$ & 5.4 & 2.1 & $1.6-3.9$ & 4.2 & 4.4 & 5 & 7.2 & 14.7 & $8.6-14.7$ & \\
\hline $\mathrm{H}_{2} \mathrm{~S}(\mathrm{mM})$ & 2 & 3.6 & $1.8-3.9$ & 5.6 & 5.2 & 23 & 13.5 & & & 0.0000001 \\
\hline$\delta^{34} S_{\mathrm{H} 2 \mathrm{~S}}$ & +3.6 & +11 & & +3.6 to +7.7 & $\begin{array}{l}+5.5 \text { to } \\
+7.8\end{array}$ & & & & & \\
\hline $\mathrm{C}_{2} \mathrm{H}_{6}(\mathrm{uM})$ & $<1$ & $<1$ & & 0.33 & 2.5 & & & & & \\
\hline $\mathrm{CO}(\mathrm{uM})$ & & & & 30 & 63 & & & & & 0.0001 \\
\hline $\mathrm{He}(\mathrm{uM})$ & 0.68 & & & 0.72 & 0.53 & & & & & \\
\hline$\overline{3 / 4} \mathrm{He}\left(\mathrm{R}_{\mathrm{atm}}\right)$ & 6.99 & 7.1 & & 6.5 & 5.81 & & & & & 1 \\
\hline
\end{tabular}

chemistry among the global hydrothermal fields help to clarify the characteristic fluid chemistries of the OT hydrothermal fluids and their relationships with geological and tectonic backgrounds.

This chapter discusses only the 'endmember' hightemperature fluid chemistry, estimated by a Mg-diagram and extrapolation of $\mathrm{Mg}$ concentrations to zero (von Damm et al. 1985), to avoid losing focus on the inter-field comparison. Thus this chapter does not discuss secondary chemical modification associated with either low-temperature hydrothermal fluid discharges through the sedimentary environment (Gamo et al. 1991; Kawagucci et al. 2013b; Yokoyama et al. Chap. 31) or the liquid $\mathrm{CO}_{2}$ emersion and the relevant microbial ecosystems (Inagaki et al. 2006; Yanagawa et al. 


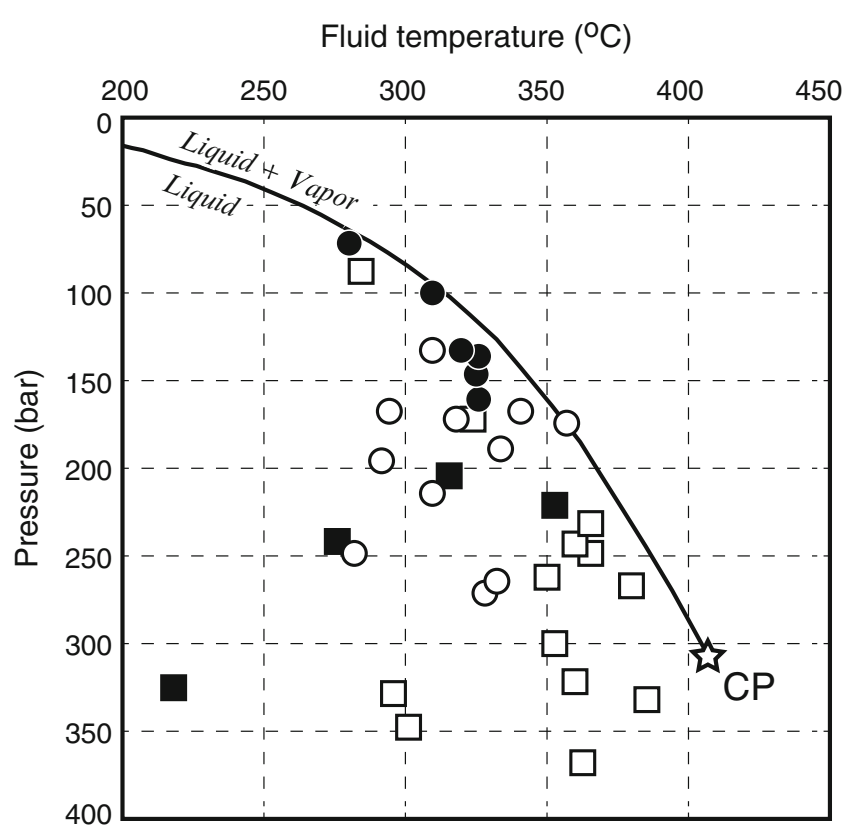

Fig. 30.2 Two-phase curve for seawater. Each symbol represents P-T conditions of venting fluids at each field from the Okinawa Trough (filled circles), sediment-associated systems (filled squares), sedimentstarved ABA systems (open circles), and sediment-starved MOR systems (open squares). An open star $(\mathrm{CP})$ represents a critical point of seawater. References for this figure are presented in Sect. 30.2.2

2013). In addition, trace elements (Mo, W, REE, etc.) measured in some OT hydrothermal fluids (Kishida et al. 2004; Hongo et al. 2007; Kawagucci et al. 2013b) are also not included in this chapter because the limited available dataset prohibits global comparison.

\subsubsection{Inter-Field (Field-to-Field) Variation and the OT Characteristics}

Figure 30.1 shows the physical properties and the $\mathrm{Mg}$-corrected endmember chemistries of high-temperature hydrothermal fluids in (1) the six OT fields (Table 30.1), (2) four sediment-associated MOR fields (Lilley et al. 1993, 2003; Proskurowski et al. 2004, 2006; von Damm et al. 2005; McCollom 2008; Ishibashi et al. 2002; Pearson et al. 2005; Gieskes et al. 2002; Butterfield et al. 1994; and references therein), (3) ten sediment-starved ABA fields (Tsunogai et al. 1994, 2005; Toki et al. 2008; Kishida et al. 2004; Ishibashi et al. 1994a, 1994b; 2002b; Grimaud et al. 1991; Reeves et al. 2011; Mottl et al. 2011; de Ronde et al. 2011; and references therein), and (4) twelve sedimentstarved MOR fields (Gamo et al. 2001; Kumagai et al. 2008; Gallant and von Damm 2006; Fouquet et al. 2010; Charlou et al. 2010; Von Damm et al. 1985; Merlivat et al. 1987; and references therein). The hydrothermal fields shown in Fig. 30.1 represent global variations in host rock chemistry (silicic, mafic, and ultramafic) and geographical distribution (the Indian Ocean, the Pacific Ocean, the Atlantic Ocean, and the adjacent seas). The endmember $\mathrm{Cl}$ concentrations are deviated from seawater $\mathrm{Cl}$ levels in almost all the hydrothermal fields (Fig. 30.1), demonstrating alteration in fluid chemistry due to the phase separation. For ion species, element/Cl ratios are used instead of concentrations to eliminate the effect of phase separation (Fig. 30.1).

The highest measured temperatures of hydrothermal fluids $\left(\mathrm{T}_{\max }\right)$ in the OT hydrothermal fields range between 280 and $326{ }^{\circ} \mathrm{C}$, which are lower than typical $\mathrm{T}_{\max }$ of the MOR fields (approximately $350{ }^{\circ} \mathrm{C}$ ). Fluid temperature is very likely constrained by pressure, which determines the fluid boiling temperature (Fig. 30.2). Because the water depths of the OT hydrothermal fields range between 700 and $1,600 \mathrm{~m}$ and are generally shallower than other hydrothermal systems (Fig. 30.1), the pressure condition (the potential of $\mathrm{T}_{\max }$ ) is lower. In fact, the fluid pressuretemperature conditions of the OT fields are very close to the two-phase boundary (Bischoff and Rosenbauer 1984) (Fig. 30.2).

The hydrothermal fluid $\mathrm{pH}$ of the OT fields, measured at $25{ }^{\circ} \mathrm{C}$ in an onboard laboratory, range from 4.65 to 5.7. This $\mathrm{pH}$ range is generally comparable with that in the sedimentassociated MOR systems ( $\mathrm{pH}=4.5-5.9)$ but higher than the $\mathrm{pH}$ ranges of sediment-starved $\mathrm{ABA}$ and MOR systems ( $\mathrm{pH}=2-5$ ) (Fig. 30.1). In addition, a low-temperature hydrothermal fluid with an extremely low $\mathrm{pH}(\leq 2.1)$ due to direct emission of magmatic $\mathrm{SO}_{2}$ to the seafloor has been observed in the DESMOS field in the eastern Manus Basin, Western Pacific (Gamo et al. 1997). The moderately acidic $\mathrm{pH}$ of the OT fluids despite the ABA tectonic background suggests that some components from sedimentary organic matter decomposition, such as millimolar levels of $\mathrm{NH}_{3} /$ $\mathrm{NH}_{4}{ }^{+}$(Table 30.1), buffer the $\mathrm{pH}$. The presence of $\mathrm{NH}_{3} /$ $\mathrm{NH}_{4}{ }^{+}$in high-temperature hydrothermal fluids is known to yield a high $\mathrm{pH}$ at the $25^{\circ} \mathrm{C}$ measurement but a lower $\mathrm{pH}$ at in situ hydrothermal conditions (Tivey et al. 1999). The OT hydrothermal fluids contain abundant $\mathrm{CO}_{2}(>40 \mathrm{mM})$ of magmatic origin, based on the carbon isotope ratios of the $\mathrm{CO}_{2}$ (Ishibashi et al. 1995; Kawagucci et al. 2011, 2013a). In contrast, the concentrations of $\mathrm{H}_{2} \mathrm{~S}$, another major component of the magma-derived volatiles, are similar between the OT and other fields, regardless of the geological/tectonic backgrounds (Fig. 30.1). The helium isotope ratios $\left({ }^{3 / 4} \mathrm{He}\right)$ of the OT hydrothermal fluids are $\leq 7.1$ and are similar to those in the sediment-associated MOR fluids (Fig. 30.1). This ${ }^{3 / 4} \mathrm{He}$ range, which is slightly lower than the typical sediment-starved MOR value of 8 (Sano and Fischer 2013), implies a contribution of crustal ${ }^{4} \mathrm{He}$-enriched helium.

The lower $\mathrm{Na} / \mathrm{Cl}$ ratios of the OT fluids (0.68-0.78) compared to the seawater $\mathrm{Na} / \mathrm{Cl}$ ratio (0.86) suggest $\mathrm{Na}$ 
uptake into the solid phase during subseafloor fluid circulation (Fig. 30.1). High $\mathrm{K} / \mathrm{Cl}$ ratios are typical characteristics of hydrothermal fields in ABA systems, including the OT fields (>0.09) (Fig. 30.1). The $\mathrm{K}$ enrichment in the ABA fluids is attributed to probable $\mathrm{K}$ enrichment in surrounding rocks, with which fluid interacts during fluid circulation (Sakai et al. 1990a). The magnitudes of Na-loss and K-gain in each OT field seem consistent between each other (Fig. 30.1), implying quantitative exchange of $\mathrm{Na}$ for $\mathrm{K}$ during fluid-mineral interaction. In addition, a geographical trend in the $\mathrm{K} / \mathrm{Cl}$ variation within the OT is also found: higher $\mathrm{K} / \mathrm{Cl}$ ratios in southern OT fields (Daiyon-Yonaguni and Hatoma) than in northern OT fields (particularly Minami-Ensei). This trend may reflect a difference in the $\mathrm{K}$ content of the basement rocks, although there is little data on the host rock chemistry of the OT hydrothermal fields (Shinjo and Kato 2000). The $\mathrm{Ca} / \mathrm{Cl}$ ratios are lower in the OT fields $(<0.05)$ than in the others, including sedimentassociated MOR fields (Fig. 30.1). The $\mathrm{Li} / \mathrm{Cl}$ ratios are substantially higher in all of the OT fields $(>0.002)$ than in the other fields. Because of the almost quantitative partitioning of alkali elements into the fluid phase during high-temperature fluid-rock (-sediment) interactions, the high $\mathrm{Li} / \mathrm{Cl}$ ratios in the OT fluids suggest $\mathrm{Li}$ enrichment in the OT basement rocks and/or the OT-filling sediment. Low $\mathrm{Fe} / \mathrm{Cl}$ ratios $(<0.001)$ are typical in the sediment-associated fields while the low $\mathrm{Fe} / \mathrm{Cl}$ ratios of the OT fluids may be associated with low $\mathrm{T}_{\max }$. The $\mathrm{Mn} / \mathrm{Cl}$ ratios are similar regardless of tectonic/geological background, excluding several ABA fields where the $\mathrm{Mn} / \mathrm{Cl}$ ratios are extremely high. The $\mathrm{Sr} / \mathrm{Cl}$ ratios so far observed in hydrothermal fluids vary among the fields regardless of tectonic/geological backgrounds. The hydrothermal fluid $\mathrm{Sr} / \mathrm{Cl}$ range, higher or lower than the seawater $\mathrm{Sr} / \mathrm{Cl}$ ratio in each field, indicates that both net gain and loss of Sr from the starting seawater during the hydrothermal fluid circulation is possible. Strontium isotope ratios $\left({ }^{87 / 86} \mathrm{Sr}\right)$ are high $(\geq 0.709)$ in the OT Minami-Ensei and Jade fields (Noguchi et al. 2011) and a sediment-covered Escanaba field but low (approximately 0.704) in sediment-starved MOR and ABA fields and sediment-covered Guaymas and Middle Valley fields. The high ${ }^{87 / 86} \mathrm{Sr}$ ratios of the OT fluids are attributed to those in the OT-filling sedimentary component (Noguchi et al. 2011).

\subsection{Gas Species Chemistry}

\subsubsection{Methane Sources in Hydrothermal System}

The chemical origins of subseafloor $\mathrm{CH}_{4}$ are typically classified by a combination of the carbon source (inorganic or organic) and the generation process (chemical or biological,

\section{Carbon source}

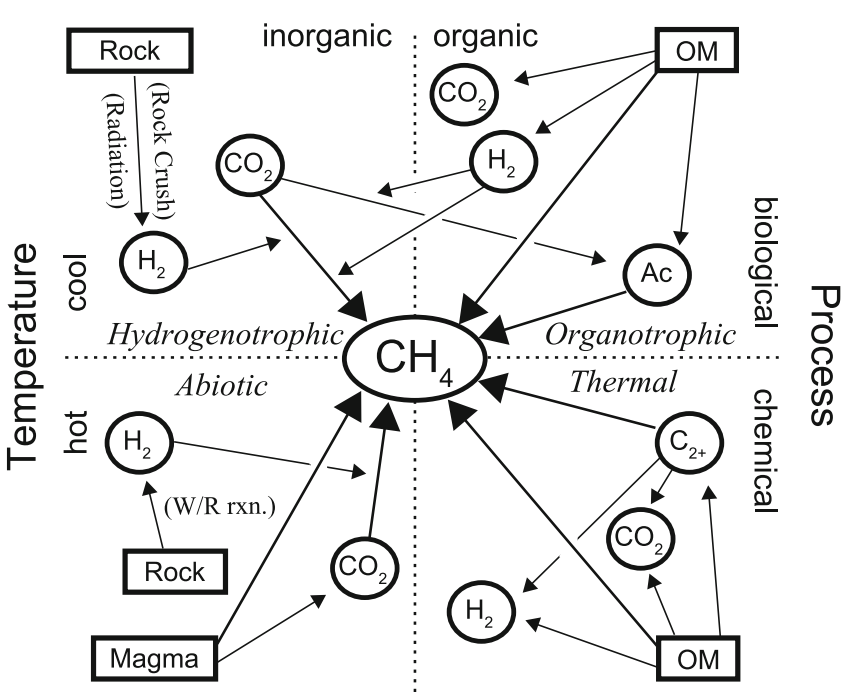

Fig. 30.3 Schematic illustrating methanogenic pathways in subseafloor geofluid systems. Ac, $\mathrm{C}_{2+}$, and $\mathrm{OM}$ represent acetate, hydrocarbons with carbon numbers $>2$, and organic matter, respectively. After Kawagucci et al. (2013a) with minor modification

which approximately correspond to high-temperature or low-temperature environments) (Fig. 30.3). This classification distinguishes three types: so-called abiotic $\mathrm{CH}_{4}$ (e.g., McCollom 2013), thermogenic $\mathrm{CH}_{4}$ (e.g., Welhan and Lupton 1987), and biogenic $\mathrm{CH}_{4}$ (e.g., Valentine et al. 2004). Abiotic $\mathrm{CH}_{4}$ has been considered to be the predominant source of hydrothermal fluid $\mathrm{CH}_{4}$ in typical sedimentstarved hydrothermal systems. However, in almost all the sediment-starved hydrothermal fields so far observed, the measured $\mathrm{CH}_{4}$ concentrations are several orders of magnitude greater (or smaller) than the $\mathrm{CH}_{4}$ concentrations that are thermodynamically predicted from the $\mathrm{H}_{2}$ and $\mathrm{CO}_{2}$ concentrations and fluid temperature of the venting fluid (McCollom 2008). While the excess could be explained by the loss of $\mathrm{H}_{2}$ and/or $\mathrm{CO}_{2}$ during fluid upwelling from the deep zone where abiotic methanogenesis has actually occurred, $\mathrm{CH}_{4}$ derived from other sources could also account for the excess. Thermogenic $\mathrm{CH}_{4}$ has been thought to be the predominant source for abundant $\mathrm{CH}_{4}$ in hydrothermal systems occurring close to sedimentary organic-rich environments, such as the OT fields (Ishibashi et al. 1995). Even if the seafloor has a sediment-starved appearance, organic matter buried beneath the seafloor is assumed to be a source for thermogenic $\mathrm{CH}_{4}$ (Lilley et al. 1993). Biogenic $\mathrm{CH}_{4}$ includes methane generated by both hydrogenotrophic and organotrophic methanogenesis. The microbial syntrophic relationship between fermentative hydrogenogenesis and hydrogenotrophic methanogenesis is expected in the sedimentary environment (Fig. 30.3). Biogenic $\mathrm{CH}_{4}$ could be incorporated into hydrothermal fluid 
only in the recharge stage of the whole fluid circulation process because the reaction zone and the discharge stage are too hot for any microbes to be active (Takai et al. 2008). The recharge stage environment, where the penetrating seawater becomes reduced and warm, is very likely suitable for anaerobic and/or thermophilic microbes.

The MMR model, which we have proposed in recent papers (Kawagucci et al. 2011, 2013a), describes the origin of hydrothermal fluid $\mathrm{CH}_{4}$ in not only geochemical terms but also geographical aspects. This model claims that $\mathrm{CH}_{4}$ in high-temperature hydrothermal fluid can originate from $\mathrm{CH}_{4}$ that is generated biologically and incorporated into the fluid in the low-temperature recharge stage of hydrothermal fluid circulation. The MMR model is emphasized particularly in the sediment-associated hydrothermal systems where the recharge stage of hydrothermal fluid circulation is expected to include an organic-rich sedimentary environment. Even if the sedimentary recharge zone is absent, methanogenic ecosystems in the crustal recharge zone might be fueled by abiotic $\mathrm{H}_{2}$ generated from serpentinization (McCollom and Bach 2009), water radiolysis (Lin et al. 2005), and/or fault activity (Hirose et al. 2011). Moreover, abiotic methanogenesis associated with serpentinization of ultramafic rocks in the recharge stage cannot be ruled out because of its kinetic and thermodynamic favorability at temperatures of $200-315{ }^{\circ} \mathrm{C}$ (McCollom and Bach 2009). Consequently, all three types of $\mathrm{CH}_{4}$ generation and their occurrence through each stage of the whole fluid circulation system should be considered to deduce the origins of $\mathrm{CH}_{4}$ in venting hydrothermal fluid.

\subsubsection{Geochemical Tracers to Deduce the Origin of Methane}

The origin of hydrothermal fluid $\mathrm{CH}_{4}$ can be deduced by using geochemical tracers, and the multiple tracers approach allows us to more accurately deduce the origin of hydrothermal fluid $\mathrm{CH}_{4}$. Although several tracers have been proposed and indeed utilized, the indications of the tracers include uncertainties in some circumstances and should be assessed carefully. This issue has already been discussed in previous papers on stable hydrogen isotope ratios $\left(\delta \mathrm{D}_{\mathrm{CH} 4}\right)$ (Kawagucci et al. 2011), stable carbon isotope ratios $\left(\delta^{13} \mathrm{C}_{\mathrm{CH} 4}\right)$, relative abundances of $\mathrm{CH}_{4}$ to non-methane hydrocarbons $\left(\mathrm{C}_{1} / \mathrm{C}_{2+}\right)$, and $\mathrm{H}_{2}$ concentrations (Kawagucci et al. 2013a). Here, a summary of the previous discussion with some additional information is presented.

\subsubsection{Methane Concentration and $\mathrm{CH}_{4} /{ }^{3} \mathrm{He}$ Ratio}

The concentration of $\mathrm{CH}_{4}$ in the venting fluid is a fundamental piece of information in deducing the origin of the $\mathrm{CH}_{4}$.

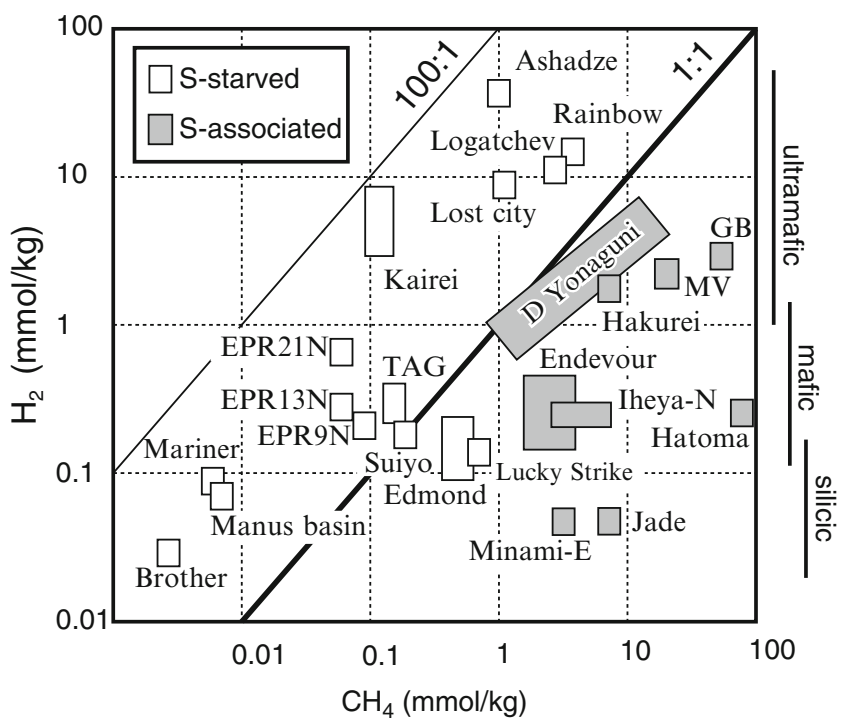

Fig. 30.4 Plots of $\mathrm{H}_{2}$ concentration versus $\mathrm{CH}_{4}$ concentration in hydrothermal fluids. Open and gray squares represent sediment-starved and sediment-associated fields, respectively. Vertical bars indicate typical $\mathrm{H}_{2}$ concentrations in reaction zone fluids for silicic, mafic, and ultra-mafic basement systems. Labels GB and MV are Guaymas Basin and Middle Valley, respectively. After Kawagucci et al. (2013a) with minor modification

The global dataset of high-temperature hydrothermal fluid compositions illustrates two approximate relationships between $\mathrm{CH}_{4}$ concentrations and geological settings. First, $\mathrm{CH}_{4}$ concentrations are significantly higher in hydrothermal fields located in sedimentary locations (Figs. 30.1 and 30.3). This type of $\mathrm{CH}_{4}$ enrichment typically accompanies enrichment in certain other components, such as ammonium, suggesting anoxic organic matter decomposition for its origin. Second, $\mathrm{CH}_{4}$ concentrations are approximately related to the redox state of the rocks exposed around the vents: higher $\mathrm{CH}_{4}$ concentrations are associated with more reduced rocks (Figs. 30.1 and 30.4). Although, again, measured $\mathrm{CH}_{4}$ concentrations are not consistent with thermodynamic predictions (McCollom 2008), more reducing conditions in the reaction zone are advantageous for abiotic methanogenesis.

The relative abundance of $\mathrm{CH}_{4}$ with ${ }^{3} \mathrm{He}\left(\mathrm{CH}_{4} /{ }^{3} \mathrm{He}\right)$ differentiates mantle-derived $\mathrm{CH}_{4}$ from crust- and sediment-derived $\mathrm{CH}_{4}$ because juvenile ${ }^{3} \mathrm{He}$ should be derived from the mantle. $\mathrm{CH}_{4} /{ }^{3} \mathrm{He}$ ratios higher than $10^{7}$ $(\mathrm{mol} / \mathrm{mol})$ are typically found in sediment-associated hydrothermal fields (Lilley et al. 1993; Ishibashi et al. 1995) and sediment-starved slow-spreading MOR fields (Charlou et al. 2000), while ratios of $10^{6}$ are reported for moderate- to fastspreading MOR hydrothermal fields (Kawagucci et al. 2008; and references therein). 


\subsubsection{Carbon and Hydrogen Isotope Ratios of Methane}

The $\delta^{13} \mathrm{C}_{\mathrm{CH} 4}$ value is the geochemical indicator most widely used to deduce the origins of environmental $\mathrm{CH}_{4}$. Expected ranges of $\delta^{13} \mathrm{C}_{\mathrm{CH} 4}$ values for each of the three types have been investigated in laboratory experiments (Fig. 30.5). The $\delta^{13} \mathrm{C}_{\mathrm{CH} 4}$ values of abiotic $\mathrm{CH}_{4}$ in the experiments ( -40 to $-20 \%$ ) (e.g., Horita and Berndt 1999; McCollom and Seewald 2006; McCollom et al. 2010) are quite different from those frequently observed in the sediment-starved hydrothermal fields ( -20 to $-5 \%$ ). The inconsistency in abiotic $\delta^{13} \mathrm{C}_{\mathrm{CH} 4}$ values remains unresolved. I suspect the reason may be due to some experimental artifacts, such as unnatural catalysts of $\mathrm{Fe}-\mathrm{Ni}$ alloy, for example. Thermogenic $\mathrm{CH}_{4}$ generated from sedimentary organic matter $\left(\delta^{13} \mathrm{C}_{\mathrm{org}}=-25\right.$ to $-20 \%$ ) likely results in $\delta^{13} \mathrm{C}_{\mathrm{CH} 4}$ values between -30 and $-20 \%$ because of small isotope fractionation, based on experiments (Seewald et al. 1994). However, larger fractionations at lower temperature (Hoefs 2009) and intra-molecular ${ }^{13} \mathrm{C}$ depletion in the methyl-carbon of longchain hydrocarbons (Gilbert et al. 2013) imply possibly more ${ }^{13} \mathrm{C}$-depleted thermogenic $\mathrm{CH}_{4}$. Although a broad $\delta^{13} \mathrm{C}_{\mathrm{CH} 4}$ range ( -50 to $-20 \%$ ) was proposed for thermogenic $\mathrm{CH}_{4}$ based on the compilation of field observations (Whiticar 1999), such a broad range may result from the mixing of 'pure' thermogenic $\mathrm{CH}_{4}$ described above with ${ }^{13} \mathrm{C}$-depleted biogenic $\mathrm{CH}_{4}(-100$ to $-40 \%$ \%) (Kawagucci et al. 2013a and references therein). The $\delta^{13} \mathrm{C}_{\mathrm{CH} 4}$ values at the time of generation might be modified by certain processes occurring during subseafloor fluid migration (e.g., carbon isotope exchange between $\mathrm{CO}_{2}-\mathrm{CH}_{4}$ ), but the $\delta^{13} \mathrm{C}_{\mathrm{CH} 4}$ modifications are expected to be negligible in terms of both reaction kinetics and/or magnitudes of the fractionation (see Kawagucci et al. 2013a for details). Consequently, the $\delta^{13} \mathrm{C}_{\mathrm{CH} 4}$ value is a robust and useful indicator for deducing the origin of subseafloor $\mathrm{CH}_{4}$.

The $\delta \mathrm{D}_{\mathrm{CH} 4}$ value has been used as an indicator to deduce the origin of environmental $\mathrm{CH}_{4}$, in addition to the $\delta^{13} \mathrm{C}_{\mathrm{CH} 4}$ value (Fig. 30.6). Many incubation experiments using both microbial isolates and bulk ecosystems (e.g., soil) revealed that biogenic $\mathrm{CH}_{4}$ displayed a typically $\mathrm{D}$-depleted isotope signature ( -350 to $-250 \%$ ) (Sugimoto and Wada 1995; Valentine et al. 2004) at the case that the $\delta \mathrm{D}_{\mathrm{H} 2 \mathrm{O}}$ value is $+0 \%$. These incubations also revealed that the empirical $\delta \mathrm{D}_{\mathrm{CH} 4} / \delta \mathrm{D}_{\mathrm{H} 2 \mathrm{O}}$ ratio is approximately 0.75 for hydrogenotrophic methanogenesis and approximately 0.25 for aceticlastic methanogenesis. In contrast, past compilations of observations from sediment, oil fields, and natural gases (Nakai et al. 1974; Whiticar 1999) proposed a broader range of $\delta \mathrm{D}_{\mathrm{CH} 4}$ values $(-450$ to $-150 \%$ o) as the "biogenic methane signature." The proposed biogenic $\delta \mathrm{D}_{\mathrm{CH} 4}$ characteristics from the compilation should be followed with care because environmental $\mathrm{CH}_{4}$ may result

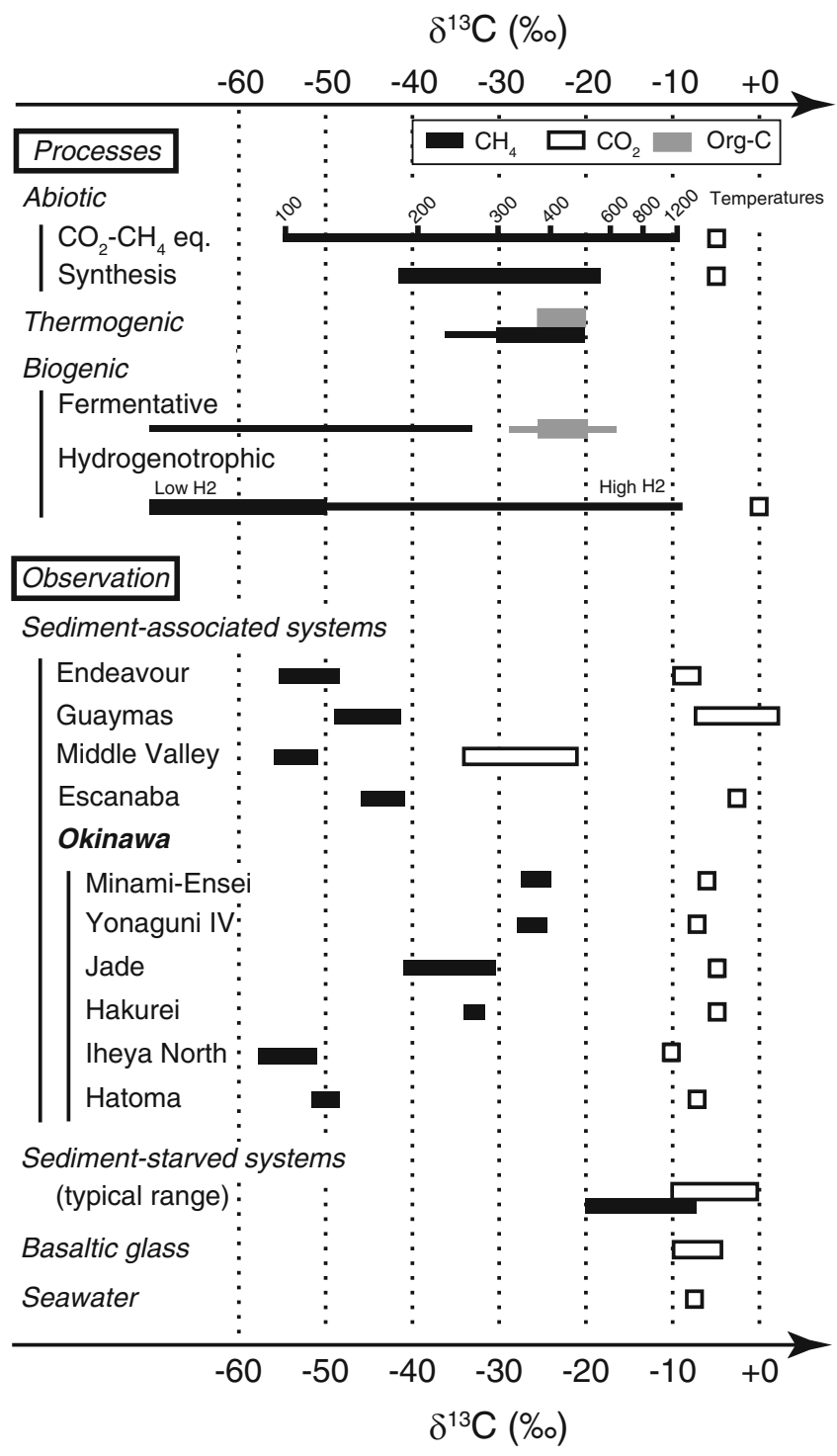

Fig. $30.5 \delta^{13} \mathrm{C}$ values of $\mathrm{CH}_{4}$ (black bars), $\mathrm{CO}_{2}$ (white boxes), and organic carbon (gray bars) considered typical for each process based on experimental and theoretical studies and observations in hydrothermal fluids. After Kawagucci et al. (2013a) with minor modification

from the mixing of multiple $\mathrm{CH}_{4}$ sources and may have been partly consumed that results in increase of $\delta \mathrm{D}_{\mathrm{CH} 4}$ value. Nevertheless, all hydrothermal $\delta \mathrm{D}_{\mathrm{CH} 4}$ values measured so far have fallen into a narrow range $(-130$ to $-96 \%$ ), regardless of the types of hydrothermal systems (Proskurowski et al. 2006; Kawagucci et al. 2011, 2013a; Reeves et al. 2011). This narrow range is very likely caused by hydrogen isotopic equilibrium between $\mathrm{CH}_{4}$ and $\mathrm{H}_{2} \mathrm{O}$ in the high-temperature fluids $\left(>250{ }^{\circ} \mathrm{C}\right.$ and $\delta \mathrm{D}_{\mathrm{H} 2 \mathrm{O}}=+0 \%$ o) that lead to $\delta \mathrm{D}_{\mathrm{CH} 4}$ values of approximately $-130 \%$ (Proskurowski et al. 2006) although the certain reaction kinetics of hydrogen isotope exchange between $\mathrm{CH}_{4}$ and $\mathrm{H}_{2} \mathrm{O}$ toward isotopic equilibrium have never been 
Fig. 30.6 Plots of $\delta \mathrm{D}_{\mathrm{CH} 4}$ values versus $\delta^{13} \mathrm{C}_{\mathrm{CH} 4}$ values. Open symbols represent the observations in the Okinawa Trough (ME: Minami-Ensei; Izena: Jade and Hakurei). Light gray areas represent typical ranges of sediment-starved and associated fields as labeled. Dark gray areas represent the expected ranges for thermogenic, biogenic, and abiotic methane, where the values of $\delta^{13} \mathrm{C}_{\text {DIC }}(-25$ to $+0 \%$ ), $\delta^{13} \mathrm{C}_{\text {org }}$ (-25 to $-20 \%$ ), and $\delta \mathrm{D}_{\mathrm{H} 2 \mathrm{O}}(+0 \%)$ are assumed for a methanogenic environment (see literature for details). An arrow and a horizontal break line represent the direction of $\delta \mathrm{D}_{\mathrm{CH} 4}$ change on the hydrogen isotope exchange between $\mathrm{H}_{2} \mathrm{O}$ and $\mathrm{CH}_{4}$ and the value at the isotope equilibrium, respectively. Diagonal dotted lines represent typical co-variation of $\delta^{13} \mathrm{C}-\delta \mathrm{D}$ in microbial methane consumption $\left(\Delta \delta \mathrm{D} / \Delta \delta^{13} \mathrm{C}=8-10\right)$

(Feisthauer et al. 2011)

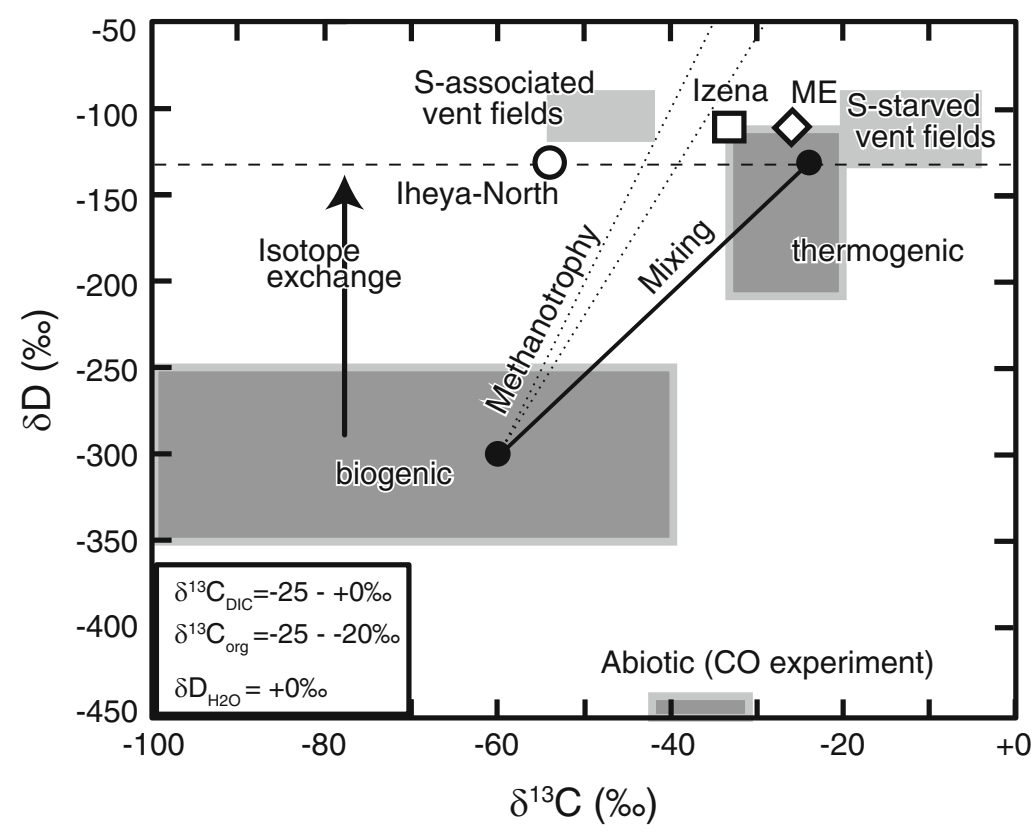

constrained (Reeves et al. 2012). While no experiment has yet verified the $\delta \mathrm{D}_{\mathrm{CH} 4}$ value of thermogenic $\mathrm{CH}_{4}$, the $\delta \mathrm{D}_{\mathrm{CH} 4}$ values would be dominated by subsequent isotope exchange resulting in the isotopic equilibrium due to the obligatory high temperature. In addition, experimentally estimated $\delta \mathrm{D}_{\mathrm{CH} 4}$ values for abiotic $\mathrm{CH}_{4}$ (e.g., approximately $-500 \%$ ) (McCollom et al. 2010) (Fig. 30.6) are quite different from the isotopically equilibrated $\delta_{\mathrm{CH} 4}$ values, despite high-temperature condition for the methanogenesis. The presence of both equilibrated $\delta \mathrm{D}_{\mathrm{CH} 4}$ values and nonequilibrated $\delta^{13} \mathrm{C}_{\mathrm{CH} 4}$ values in a $\mathrm{CH}_{4}$ reservoir would be reasonable because the molecular geometry of $\mathrm{CH}_{4}$ (carbon as a central atom and hydrogen as terminal atoms) suggests more rapid exchange of hydrogen. Consequently, the $\delta \mathrm{D}_{\mathrm{CH} 4}$ value is, in general, not useful in deducing the origin of hydrothermal fluid $\mathrm{CH}_{4}$ due to the predominance of secondary isotope exchange. However, co-variation of $\delta^{13} \mathrm{C}$ and $\delta \mathrm{D}$ $\left(\Delta \delta \mathrm{D} / \Delta \delta^{13} \mathrm{C}=8-10\right)$ has been identified in microbial methanotrophic activity (Feisthauer et al. 2011). Therefore, combination measurements between $\delta \mathrm{D}_{\mathrm{CH} 4}$ and $\delta^{13} \mathrm{C}_{\mathrm{CH} 4}$ for a series of fluid samples provides supporting information for discussion of whether the $\delta^{13} \mathrm{C}_{\mathrm{CH} 4}$ values of the samples have been altered by microbial methanotrophy (Fig. 30.6).

The radioactive carbon in $\mathrm{CH}_{4}\left(\Delta^{14} \mathrm{C}_{\mathrm{CH}}\right)$ is a possible tracer. Because magma-derived carbon should be ${ }^{14} \mathrm{C}$-dead, detectable ${ }^{14} \mathrm{C}$ in hydrothermal fluid $\mathrm{CH}_{4}$ indicates carbon input from seawater or young sediment. Therefore, detectable ${ }^{14} \mathrm{C}$ in the hydrothermal fluid $\mathrm{CH}_{4}$, if present, implies microbial methanogenesis in the recharge stage of hydrothermal fluid circulation as a dominant $\mathrm{CH}_{4}$ source. As far as the author is aware, only one study, which used samples from the sediment-covered Guaymas hydrothermal field, has reported ${ }^{14} \mathrm{C}$ measurements of high-temperature hydrothermal fluid $\mathrm{CH}_{4}$ (Pearson et al. 2005) that revealed ${ }^{14} \mathrm{C}$-dead $\mathrm{CH}_{4}$ in hydrothermal fluid.

\subsubsection{Molecular Hydrogen and Non-methane Hydrocarbons}

The concentration of $\mathrm{H}_{2}$ in hydrothermal fluid primarily depends on the redox conditions of the high-temperature hydrothermal reaction zone. In fact, a clear relationship between the host rock type (ultramafic to silicic) and the measured $\mathrm{H}_{2}$ concentration has been identified in sedimentstarved fields (Fig. 30.4). The relationship is also found even in several sediment-associated fields, such as the OT Minami-Ensei and Jade fields (Fig. 30.4). Because $\mathrm{H}_{2}$ is likely buffered in the reaction zone by rapid reaction kinetics, additions of $\mathrm{H}_{2}$ in the recharge stage of hydrothermal fluid circulation would be diminished in the reaction zone and never detectable in the venting fluid. In turn, because sub-millimolar levels of $\mathrm{H}_{2}$ are expected from mafic host rocks, the measured millimolar levels of $\mathrm{H}_{2}$ in hydrothermal fluids in the fully sediment-covered mafic-hosted Guaymas and Middle Valley fields are attributed to thermogenic $\mathrm{H}_{2}$ input during the discharge stage of hydrothermal fluid circulation. Consequently, the $\mathrm{H}_{2}$ concentration of the venting fluid is a useful indicator in determining whether thermal fluid-sediment interaction occurred in the discharge stage. 


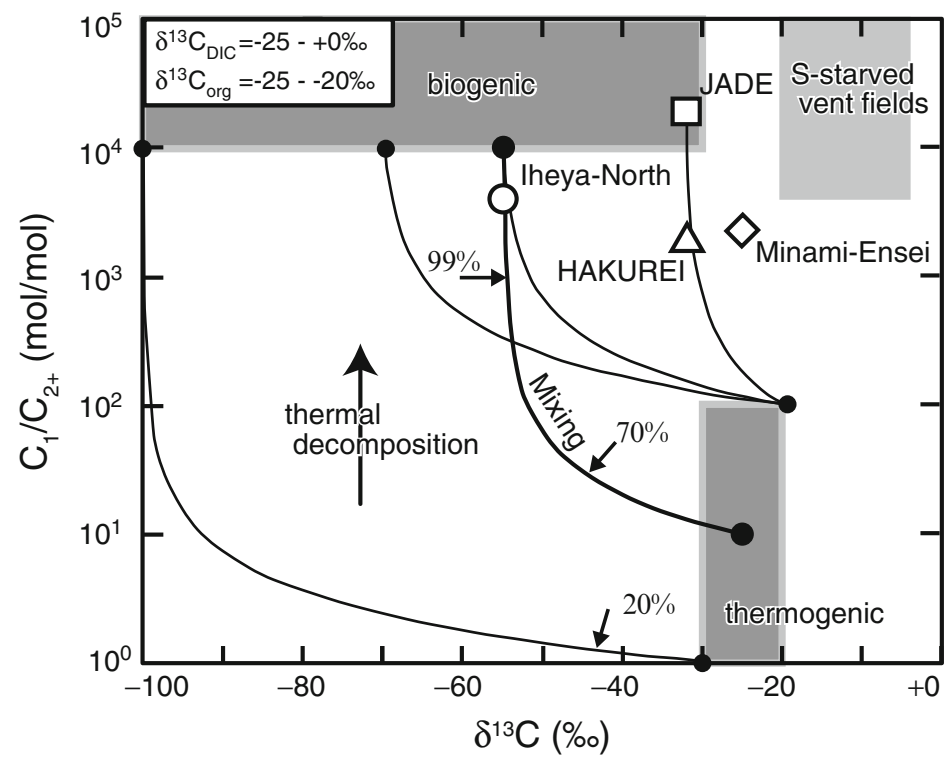

Fig. 30.7 A diagram of $\mathrm{C}_{1} / \mathrm{C}_{2+}$ ratios versus $\delta^{13} \mathrm{C}_{\mathrm{CH} 4}$ values. Gray areas represent the expected ranges of each hydrocarbon source, estimated by assuming $\delta^{13} \mathrm{C}_{\text {DIC }}(-25 \%$ o to $+0 \%)$ and $\delta^{13} \mathrm{C}_{\text {org }}(-25$ to $-20 \%$ ) (see Kawagucci et al. (2013a)). Abiotic methane range is not described. Five curves demonstrate bimodal mixing scenarios between biogenic and thermogenic hydrocarbons. The bold curve is considered the most likely scenario for subseafloor environments in sediment-associated hydrothermal systems at this time. Arrows with percentages present contributions of biogenic methane at the arrowed points of the bimodal mixing curves. Open symbols represent the measured values in each Okinawa Trough hydrothermal field. After Kawagucci et al. (2013a) with minor modification
The $\mathrm{C}_{1} / \mathrm{C}_{2+}$ ratio has been often utilized to deduce the origins of subseafloor $\mathrm{CH}_{4}$ (Fig. 30.7). Although hydrothermal experiments demonstrating abiotic $\mathrm{CH}_{4}$ generation have shown broad ranges of $\mathrm{C}_{1} / \mathrm{C}_{2+}$ ratios of $>10^{3}$ (Horita and Berndt 1999) and approximately 3 (McCollom and Seewald 2006; McCollom et al. 2010), the observed range in sediment-starved hydrothermal fields is typically $>10^{3}$ (McCollom 2008 and references therein). The difference may be due to experimental artifacts, such as the use of unnatural catalysts of native iron, for example. Microbial methanogenesis accompanies little $\mathrm{C}_{2+}$ hydrocarbon generation and is expected to feature $\mathrm{C}_{1} / \mathrm{C}_{2+}$ ratios of $>10^{4}$ (Kawagucci et al. 2013a; and references therein). While the $\mathrm{C}_{1} / \mathrm{C}_{2+}$ ratios of thermogenic hydrocarbons under hightemperature hydrothermal conditions have not yet been experimentally verified, a $\mathrm{C}_{1} / \mathrm{C}_{2+}$ ratio of $<10^{2}$ has been practically used as a thermogenic hydrocarbon signature (e. g., Whiticar 1999). It should be noted that thermal decomposition of $\mathrm{C}_{2+}$ hydrocarbons to $\mathrm{CH}_{4}$ would likely occur under deep-sea hydrothermal conditions due to both thermodynamic and kinetic aspects and could result in increasing $\mathrm{C}_{1} / \mathrm{C}_{2+}$ ratios as high as those of abiotic/biogenic $\mathrm{CH}_{4}$ (Kawagucci et al. 2013a). It should also be noted that a $\mathrm{C}_{1} /$ $\mathrm{C}_{2+}$ ratio resulting from bimodal mixing between typical thermogenic hydrocarbons and biogenic $\mathrm{CH}_{4}$ is not linearly correlated with the mixing ratio of $\mathrm{CH}_{4}$ between these hydrocarbons (Fig. 30.7). Consequently, low $\mathrm{C}_{1} / \mathrm{C}_{2+}$ ratios $\left(<10^{3}\right)$ are a definite indication of thermogenic hydrocarbons contributions to the fluid, whereas higher $\mathrm{C}_{1}$ / $\mathrm{C}_{2+}$ ratios $\left(>10^{3}\right)$ do not rule out involvement of thermogenic hydrocarbons.

\subsection{Estimation of Fluid Circulation Path: Implications of Methane Geochemistry}

By using the multiple tracers discussed above, the geochemical origins of the hydrothermal fluid $\mathrm{CH}_{4}$ in each OT field and the relationships with the geological settings can be modeled in two-dimension schematic illustrations (Fig. 30.8). This modeling enables us to deduce the geographical distribution of hydrothermal fluid circulation (Kawagucci et al. 2013a). I attempt to discover the geographical distribution of fluid circulations for all six OT hydrothermal fields, with the addition of the OT bathymetry. It should be noted that almost all of the hydrothermal fluid vents of the OT fields are hosted in volcanic bodies that outcrop from the sediment that fills the OT.

\subsubsection{Iheya North}

The Iheya North hydrothermal fluid features low $\delta^{13} \mathrm{C}_{\mathrm{CH} 4}$ values ( -58 to $-51 \%$ ), high $\mathrm{C}_{1} / \mathrm{C}_{2+}$ ratios $(>3,700)$, equilibrated $\delta \mathrm{D}_{\mathrm{CH} 4}$ values $(-130 \%)$, and low $\mathrm{H}_{2}$ 

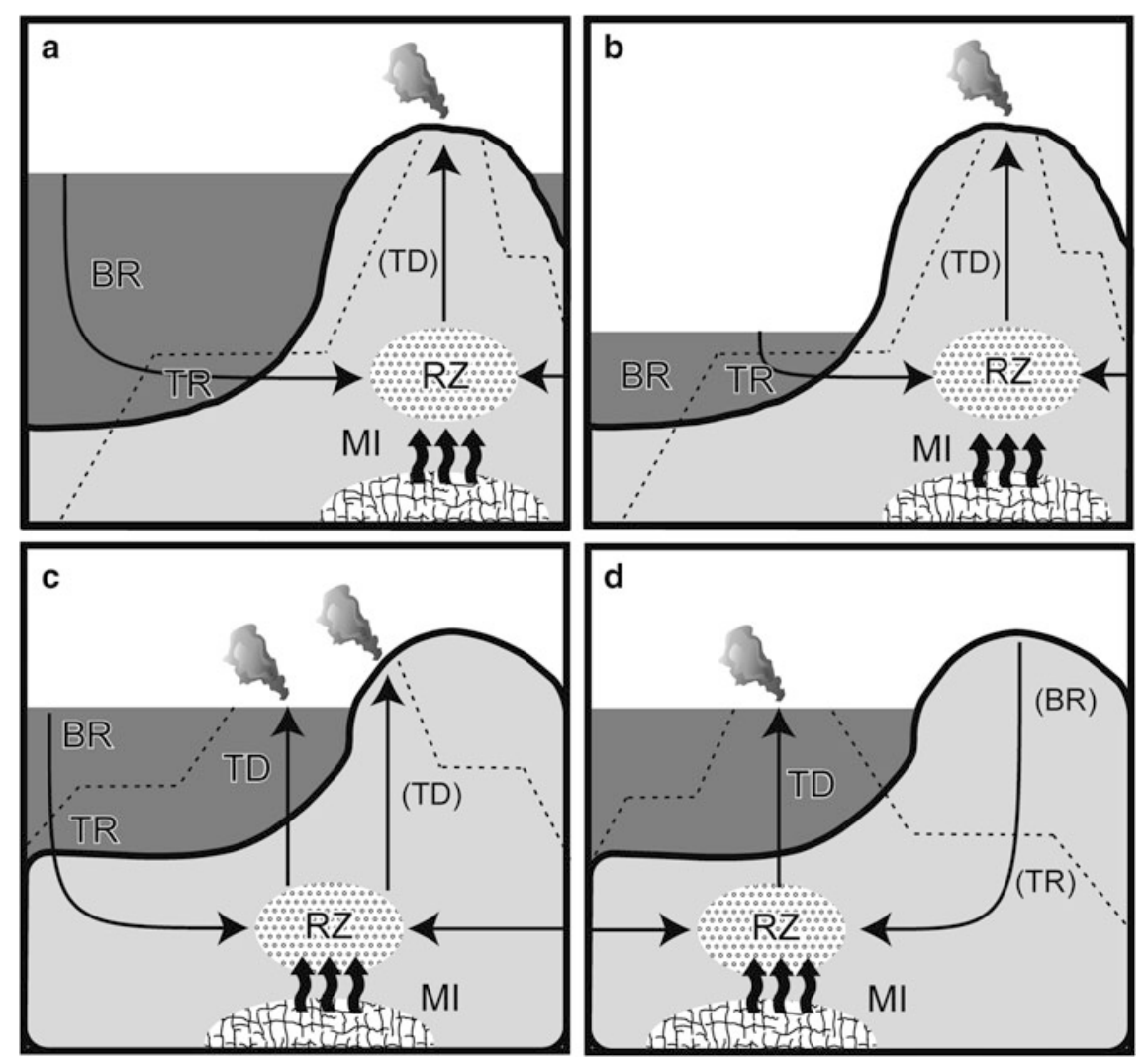

Fig. 30.8 Schematic illustrations of the 2D model representing methane origins based on the MMR model (after Kawagucci et al. (2011, 2013a) with minor modification). The geological setting and possible processes controlling fluid geochemistry, along with fluid circulation, are described (not to scale). White, dark-gray, and light-gray fields represent the seawater column, seafloor sediment, and rock basement, respectively. Arrows represent hydrothermal fluid migration paths. The two character designations represent the following: $B R$ biological

concentrations ( 0.2 mM) (Kawagucci et al. 2011, 2013b). The low $\delta^{13} \mathrm{C}_{\mathrm{CH} 4}$ values strongly suggest biogenic $\mathrm{CH}_{4}$ as the dominant geochemical origin. The high $\mathrm{C}_{1} / \mathrm{C}_{2+}$ ratios and the low $\mathrm{H}_{2}$ concentrations eliminate the possibility of thermal fluid-sediment interaction during the discharge stage. All these geochemical indications can be consistently explained by dominance of microbial methanogenesis in the recharge stage as the origin of hydrothermal fluid $\mathrm{CH}_{4}$ (Kawagucci et al. 2011) (Fig. 30.8a). Carbon mass balance calculations for the Iheya North hydrothermal system, as well as subseafloor hydrogeological structures revealed by geophysical study (Tsuji et al. 2012), suggest that the recharge stage of the Iheya North hydrothermal system includes the spatially abundant OT-filling sediments surrounding the Iheya North Knoll. This requires more than several kilometers of subseafloor hydrothermal fluid migration from the OT-filling sediment to the NBC vent (Fig. 30.9a).

processes during the Recharge stage, $T R$ thermal fluid-sediment interaction during the Recharge stage, $M I$ magmatic volatile Inputs, $R Z$ reaction zone, and $T R$ thermal fluid-sediment interaction during the Discharge stage. Dashed lines are conceptual isotherms indicating the boundary between the microbial activity-dominated region and the thermochemical reaction-dominated region. Panels correspond to the models for describing (a) Iheya North and Hatoma, (b) Minami-Ensei, (c) Jade and Hakurei, and (d) Daiyon-Yonaguni

\subsubsection{Minami-Ensei}

The Minami-Ensei hydrothermal fluid features high $\delta^{13} \mathrm{C}_{\mathrm{CH} 4}$ values $(-25 \%)$, high $\mathrm{C}_{1} / \mathrm{C}_{2+}$ ratios $(>1,710)$, nearly equilibrated $\delta \mathrm{D}_{\mathrm{CH} 4}$ values $(-105 \%)$, and low $\mathrm{H}_{2}$ concentrations (0.04 mM) (Fig. 30.4) (Kawagucci et al. 2013a). The high $\delta^{13} \mathrm{C}_{\mathrm{CH} 4}$ values strongly suggest predominance of thermogenic $\mathrm{CH}_{4}$ as its geochemical origin while the low $\mathrm{H}_{2}$ concentrations rule out thermal fluid-sediment interaction during the discharge stage. These geochemical indications can be explained by dominance of thermal fluidsediment interaction occurring in the recharge stage and reaction zone of hydrothermal fluid circulation as the origin of hydrothermal fluid $\mathrm{CH}_{4}$ (Kawagucci et al. 2013a) (Fig. 30.8b). Less biogenic $\mathrm{CH}_{4}$ contribution in the Minami-Ensei fluid implies a laterally shrunken hydrothermal fluid circulation that minimizes incorporation of biogenic $\mathrm{CH}_{4}$ from the OT-filling sediment. This model seems 
consistent with the large volcanic body of the Minami-Ensei Knoll (approximately $700 \mathrm{~m}$ in height and $5 \mathrm{~km}$ in radius) (Fig. 30.9b).

\subsubsection{Izena Hall (Jade and Hakurei)}

The Jade and Hakurei hydrothermal fluids are known to have identical fluid geochemistry, including moderate $\delta^{13} \mathrm{C}$ values $(-32 \%)$ and the nearly equilibrated $\delta \mathrm{D}$ values $(-113 \%$ \%) (Table 30.1) (Ishibashi et al. 2014). However, there are significant differences in $\mathrm{C}_{2} \mathrm{H}_{6}$ concentrations $\left(\mathrm{C}_{1} /\right.$ $\mathrm{C}_{2+}=14,900$ for Jade and $\mathrm{C}_{1} / \mathrm{C}_{2+}=2,730$ for Hakurei) and $\mathrm{H}_{2}$ concentrations $(0.06 \mathrm{mM}$ for Jade and $1.4 \mathrm{mM}$ for Hakurei). The almost identical fluid geochemistry can be explained by the fact that the Jade and Hakurei fluids likely share a common fluid reservoir, which means that they share a common fluid circulation system for the recharge stage and reaction zones (Fig. 30.8c) (Ishibashi et al. 2014). This model does not conflict with the identical $\delta^{13} \mathrm{C}_{\mathrm{CH} 4}$ and $\delta \mathrm{D}_{\mathrm{CH} 4}$ values at the case that the hydrothermal fluid $\mathrm{CH}_{4}$ of these fields are mainly derived from the recharge stage of hydrothermal fluid circulation. The moderate $\delta^{13} \mathrm{C}_{\mathrm{CH} 4}$ value suggests concomitant biogenic and thermogenic $\mathrm{CH}_{4}$ in the recharge stage. In turn, the relatively low $\mathrm{C}_{1} / \mathrm{C}_{2+}$ ratios (Fig. 30.7) and high $\mathrm{H}_{2}$ concentrations of the Hakurei fluid (Fig. 30.4) suggest thermal fluid-sediment interaction during the discharge stage. Because the sedimentary settings of the discharge stages are quite different between the fields (thick sediment-covered Hakurei field and sediment-starved Jade field), it is reasonable that thermogenic hydrocarbons and molecular hydrogen entrained into the upwelling fluid occur only in the Hakurei field (Fig. 30.8c) (Kawagucci et al. 2010a; Ishibashi et al. 2014). Hydrothermal fluid reservoir underlying the southern part of the bottom and north-eastern inner wall of the Izena Hall imply that the fluid recharge occurs not only within the Izena Cauldron but also in the volcanic body of the Izena Hall and the OT-filling sediment surrounding the Izena Hall, $>4 \mathrm{~km}$ from the vents (Fig. 30.9c).

\subsubsection{Daiyon-Yonaguni}

The Daiyon-Yonaguni hydrothermal fluids have high $\delta^{13} \mathrm{C}$ values $\left(-26 \%\right.$ ) and high $\mathrm{H}_{2}$ concentrations $(0.8-5.5 \mathrm{mM})$, but no $\mathrm{C}_{1} / \mathrm{C}_{2+}$ ratios or $\delta \mathrm{D}$ values have been reported (Konno et al. 2006). The millimolar levels of $\mathrm{H}_{2}$ concentration, despite the most likely silicic rock-hosted hydrothermal system (Fig. 30.4), suggest thermal fluid-sediment interaction occurs in the discharge stage (Fig. 30.8d). This interpretation is consistent with the high $\delta^{13} \mathrm{C}$ values that indicate that thermogenic $\mathrm{CH}_{4}$ is the dominant $\mathrm{CH}_{4}$ source. The geochemical origin of the hydrothermal fluid $\mathrm{CH}_{4}$, particularly less biogenic $\mathrm{CH}_{4}$, implies that the outcropping knolls surrounding the fluid venting area serve as the recharge zone of hydrothermal fluid circulation: Such fluid recharge reduces incorporation of biogenic $\mathrm{CH}_{4}$ from the sediment surrounding the Daiyon-Yonaguni knoll (Fig. 30.8d). Seafloor sediment of the fluid venting area, a valley of the small knolls, hosts thermal fluid-sediment interaction during fluid upwelling, which increases $\mathrm{H}_{2}$ in the fluid (Fig. 30.8d). Assuming the above model, the lateral extent of the hydrothermal fluid circulation is $<4 \mathrm{~km}$ in radius from the vents (Fig. 30.9d).

\subsubsection{Hatoma}

The Hatoma hydrothermal fluids feature low $\delta^{13} \mathrm{C}$ values ( $-50 \%$ ) (Saegusa et al. 2006) and low $\mathrm{H}_{2}$ concentrations $(0.3 \mathrm{mM})$ (Kawagucci et al. 2010b). Although no $\mathrm{C}_{1} / \mathrm{C}_{2+}$ ratios or $\delta \mathrm{D}$ values have been reported, the geochemical origin of $\mathrm{CH}_{4}$ in the Hatoma fluid can be explained by a model similar to that of the Iheya North field: Biogenic $\mathrm{CH}_{4}$ is incorporated during the recharge stage of fluid circulation while there is little involvement of thermogenic compounds (Fig. 30.8a). Because the Hatoma Knoll is small (approximately $1 \mathrm{~km}$ in radius) compared with the other OT knolls hosting high-temperature hydrothermal fields (Fig. 30.9), the OT-filling sediments surrounding the Hatoma Knoll are likely the recharge stage for hydrothermal fluid circulation and the source of biogenic $\mathrm{CH}_{4}$ in the vent fluid (Fig. 30.9e).

\subsection{Concluding Remarks}

This chapter provides a compilation of high-temperature hydrothermal fluid geochemistry from the OT hydrothermal fields. The generation of the 'TAIGA of Methane' (in other words, how and where fluid-sediment interaction occurs within a hydrothermal system) is classified by the geochemical and geographical origins of the venting methane into three patterns: (1) microbial methanogenesis in the sedimentary environment during the recharge stage, (2) thermal degradation of sedimentary organic matter during the recharge stage, and (3) thermal degradation of sedimentary organic matter during high-temperature hydrothermal fluid upwelling through the sediment layer beneath the vent (Fig. 30.8). The discussion of the origins of $\mathrm{CH}_{4}$ provides implications for the lateral extents of hydrothermal fluid circulation in each OT field (Fig. 30.9), such as larger contribution of biogenic $\mathrm{CH}_{4}$ relating to more widespread recharge zone. However, this remains highly speculative. To strengthen the model, an understanding of subseafloor hydrogeological conditions via analysis of seismic reflection 

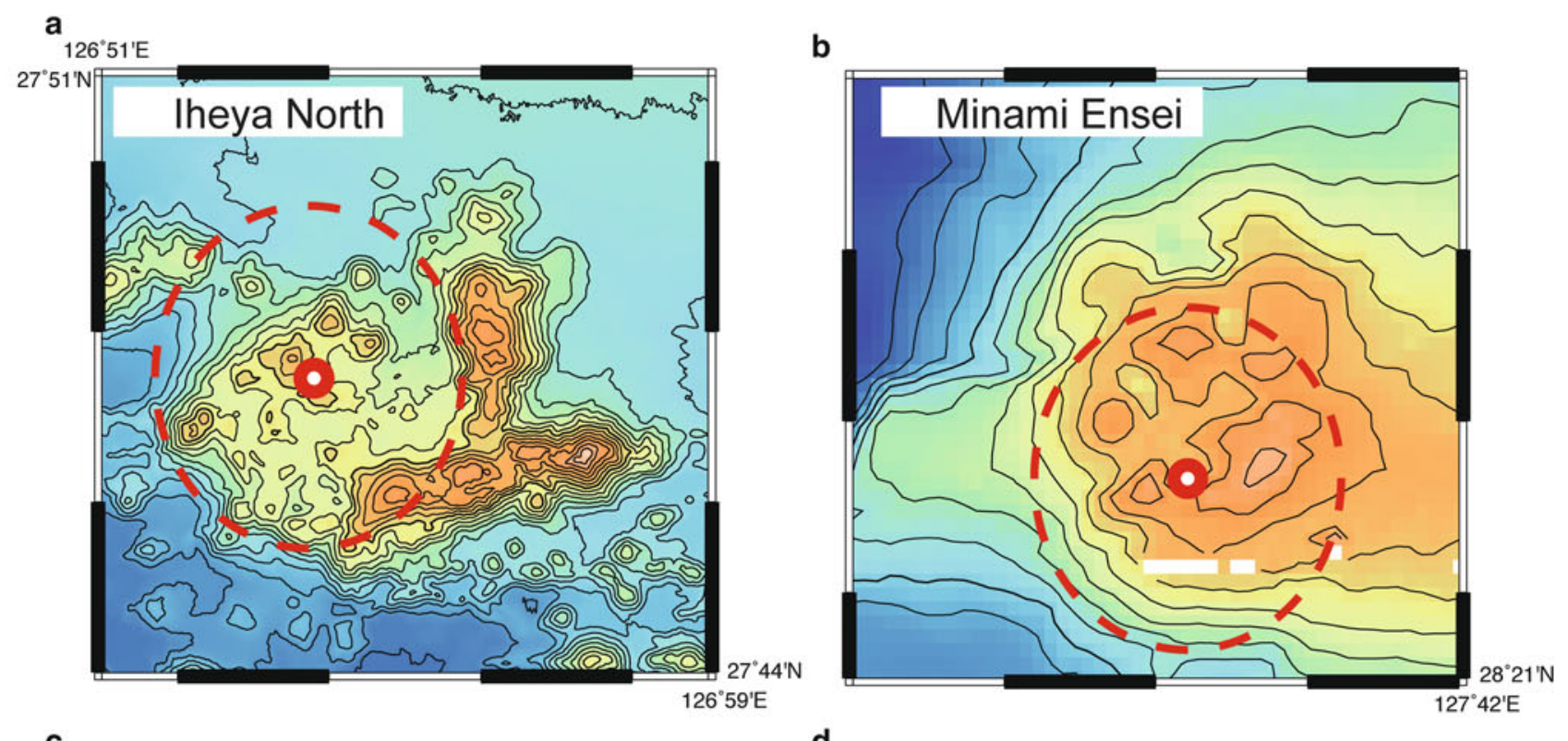

C

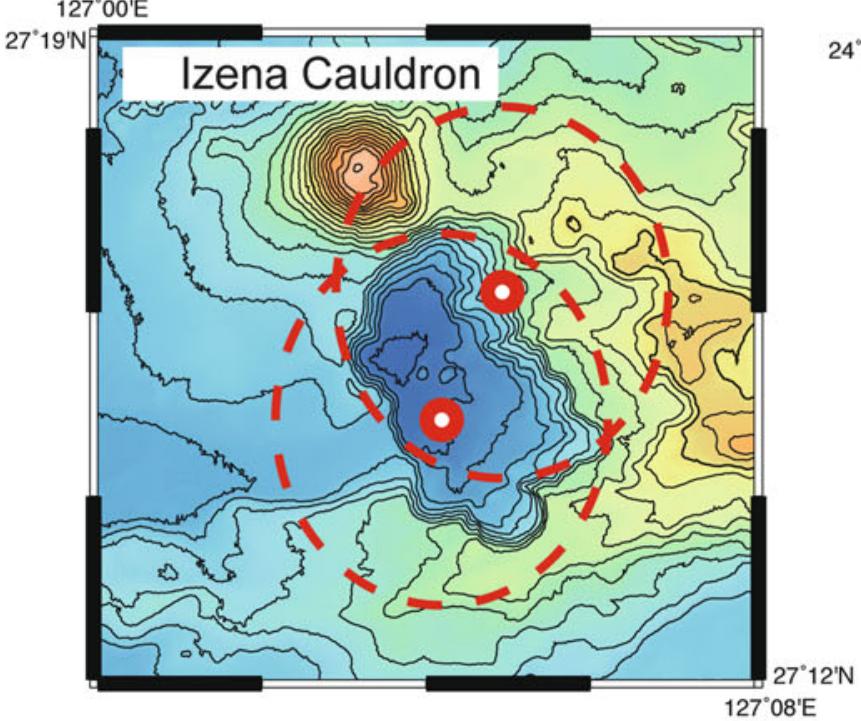

d

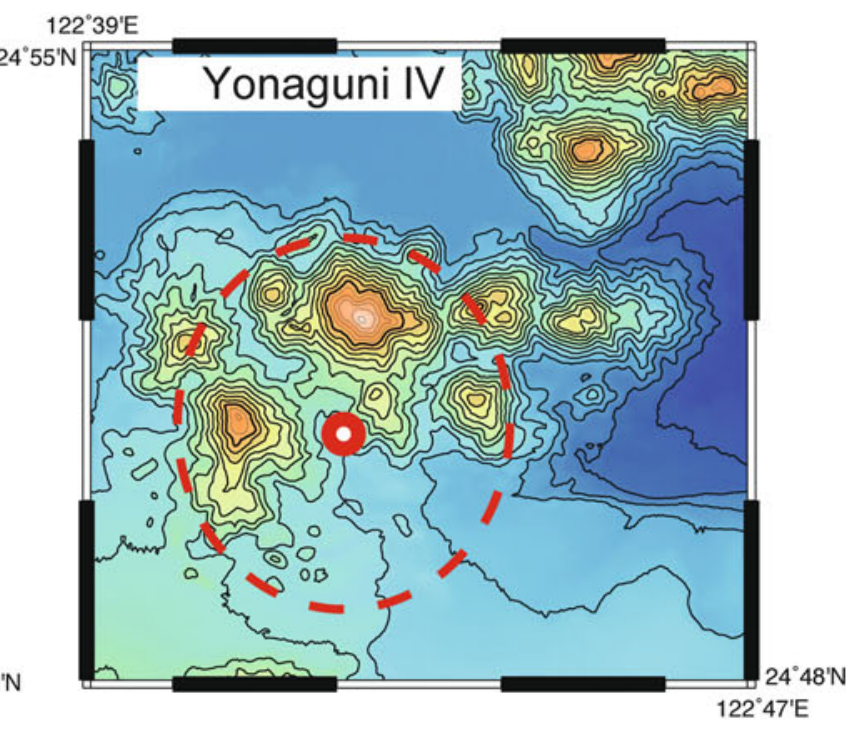

e

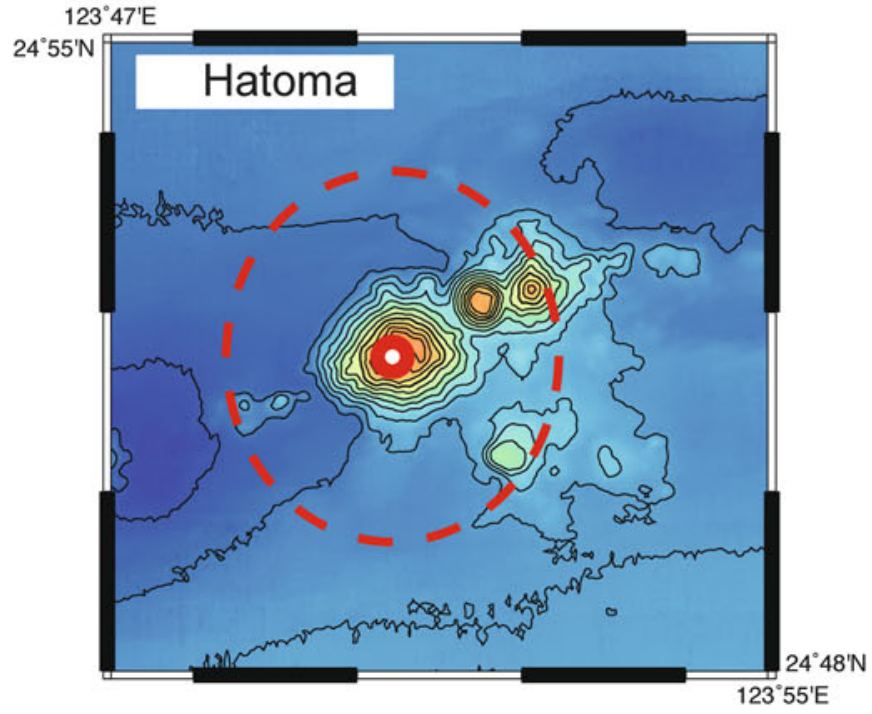

Fig. 30.9 Bathymetry maps of the six high-temperature hydrothermal fields at the same horizontal scale (coloring of depths is independent among the maps). Broken red circles on the maps represent the 2-miles radius from the main vent for each hydrothermal field 
data and measurement of the permeability of cored rocks from seafloor drilling is essential. Nevertheless, the multiple geochemical tracer approach, when combined with interdisciplinary geological and microbiological investigations, will be a great breakthrough in clarifying the geochemical and geographical origins of $\mathrm{CH}_{4}$ and associated hydrocarbons not only in deep-sea hydrothermal systems but also in the other sub(sea)floor geofluid systems, including subseafloor methane hydrate.

Acknowledgements I appreciate Ken Takai and the members of the TAIGA project for their valuable collaboration in studying deep-sea hydrothermal activity in the Okinawa Trough.

Open Access This chapter is distributed under the terms of the Creative Commons Attribution Noncommercial License, which permits any noncommercial use, distribution, and reproduction in any medium, provided the original author(s) and source are credited.

\section{References}

Bischoff JL, Rosenbauer RJ (1984) The critical-point and 2-phase boundary of seawater, $200-500^{\circ} \mathrm{C}$. Earth Planet Sci Lett 68 (1):172-180

Butterfield DA, Mcduff RE, Mottl MJ, Lilley MD, Lupton JE, Massoth GJ (1994) Gradients in the composition of hydrothermal fluids from the endeavor segment vent field - phase-separation and brine loss. J Geophys Res Solid Earth 99(B5):9561-9583

Butterfield DA, Seyfried WE Jr, Lilley MD (2003) Composition and evolution of hydrothermal fluids. In: Halbach PE, Tunnicliffe V, Hein JR (eds) Energy and mass transfer in marine hydrothermal systems. Dahlem University Press, Germany, pp 124-161

Butterfield DA et al (2004) Mixing, reaction and microbial activity in the sub-seafloor revealed by temporal and spatial variation in diffuse flow vents at axial volcano. In: Wilcock WSD, Delong EF, Kelley DS, Baross JA, Cary CS (eds) The subseafloor biosphere at mid-ocean ridges. AGU, Washington, DC, pp 269-289

Charlou JL, Donval JP, Douville E, Jean-Baptiste P, Radford-Knoery J, Fouquet Y, Dapoigny A, Stievenard M (2000) Compared geochemical signatures and the evolution of menez Gwen $\left(37^{\circ} 50^{\prime} \mathrm{N}\right)$ and lucky strike $\left(37^{\circ} 17^{\prime} \mathrm{N}\right)$ hydrothermal fluids, south of the Azores triple junction on the Mid-Atlantic ridge. Chem Geol 171 $(1-2): 49-75$

Charlou JL, Donval JP, Konn C, Ondréas H, Fouquet Y, Jean-Baptiste $\mathrm{P}$, Fourré E (2010) High production and fluxes of $\mathrm{H}_{2}$ and $\mathrm{CH}_{4}$ and evidence of abiotic hydrocarbon synthesis by serpentinization in ultramafic-hosted hydrothermal systems on the Mid-Atlantic Ridge. In: Rona PA, Devey CW, Dyment J, Murton BJ (eds) Diversity of hydrothermal systems on slow spreading ocean ridges, vol 188 , Geophysics monograph series. AGU, Washington, DC, pp 265-296

Chiba Het al (1993) Hydrothermal activity at the Minami-Ensei Knoll. Okinawa Trough: chemical characteristics of hydrothermal solutions. JAMSTECTR Deep Sea Res 9:271-282 (in Japanese with English abstract)

de Ronde CEL et al (2011) Submarine hydrothermal activity and goldrich mineratization at Brother Volcano, Kermadec Arc, New Zealand. Miner Deposita. doi:10.1007/s00126-00011-00345-00128

Feisthauer S, Vogt C, Modrzynski J, Szlenkier M, Kruger M, Siegert M, Richnow HH (2011) Different types of methane monooxygenases produce similar carbon and hydrogen isotope fractionation patterns during methane oxidation. Geochim Cosmochim Acta 75 (5):1173-1184

Fouquet $\mathrm{Y}$ et al (2010) Geodiversity of hydrothermal processes along the Mid-Atlantic Ridge and ultramafic-hosted mineralization: a new type of oceanic $\mathrm{Cu}-\mathrm{Zn}-\mathrm{Co}-\mathrm{Au}$ volcanogenic massive sulfide deposit. In: Rona PA, Devey CW, Dyment J, Murton BJ (eds) Diversity of hydrothermal systems on slow spreading ocean ridges, vol 188, Geophysics monograph series. AGU, Washington, DC, pp 321-368

Gallant RM, Von Damm KL (2006) Geochemical controls on hydrothermal fluids from the Kairei and Edmond Vent Fields, $23^{\circ}-25^{\circ} \mathrm{S}$, Central Indian Ridge. Geochem Geophys Geosyst 7

Gamo T (1995) Wide variation of chemical characteristics of submarine hydrothermal fluids due to the secondary modification processes after high temperature water-rock interaction: a review. In: Sakai H, Nozaki Y (eds) Biogeocheimical processes and ocean flux in the western pacific. Terra Scientific Publishing Company (TERRAPUB), Tokyo, pp 425-451

Gamo T, Sakai H, Kim ES, Shitashima K, Ishibashi J (1991) High alkalinity Due to sulfate reduction in the clam hydrothermal field, Okinawa Trough. Earth Planet Sci Lett 107(2):328-338

Gamo T, Okamura K, Charlou JL, Urabe T, Auzende JM, Ishibashi J, Shitashima K, Chiba H, Shipboard Scientific Party (1997) Acidic and sulfate-rich hydrothermal fluids from the Manus back-arc basin, Papua New Guinea. Geology 25:139-142

Gamo $T$ et al (2001) Chemical characteristics of newly discovered black smoker fluids and associated hydrothermal plumes at the Rodriguez Triple Junction, Central Indian Ridge. Earth Planet Sci Lett 193(3-4):371-379

German CR, Von Damm KL (2003) 6.07 - hydrothermal processes. In: Heinrich DH, Karl KT (eds) Treatise on geochemistry. Pergamon, Oxford, pp 181-222

Gieskes JM, Simoneit BRT, Goodfellow WD, Baker PA, Mahn C (2002) Hydrothermal geochemistry of sediments and pore waters in Escanaba Trough - ODP Leg 169. Appl Geochem 17 (11): $1435-1456$

Gilbert A, Yamada K, Yoshida N (2013) Exploration of intramolecular ${ }^{13} \mathrm{C}$ isotope distribution in long chain n-alkanes (C11-C31) using isotopic ${ }^{13} \mathrm{C}$ NMR. Org Geochem 62:56-61

Grimaud D, Ishibashi J, Lagabrielle Y, Auzende JM, Urabe T (1991) Chemistry of hydrothermal fluids from the $17^{\circ} \mathrm{S}$ active-site on the north Fiji basin ridge (Sw pacific). Chem Geol 93(3-4):209-218

Hirose T, Kawagucci S, Suzuki K (2011) Mechanoradical $\mathrm{H}_{2}$ generation during simulated faulting: implications for an earthquakedriven subsurface biosphere. Geophys Res Lett 38:L17303. doi: $10.1029 / 2011$ GL048850

Hoefs J (2009) Stable isotope geochemistry, 6th edn. Springer, Berlin, p 285

Hongo Y, Obata H, Gamo T, Nakaseama M, Ishibashi J, Konno U, Saegusa S, Ohkubo S, Tsunogai U (2007) Rare earth elements in the hydrothermal system at Okinawa Trough back-arc basin. Geochem J 41:1-15

Horita J, Berndt ME (1999) Abiogenic methane formation and isotopic fractionation under hydrothermal conditions. Science 285 (5430): 1055-1057

Inagaki $\mathrm{F}$ et al (2006) Microbial community in a sediment-hosted $\mathrm{CO}_{2}$ lake of the southern Okinawa Trough hydrothermal system. Proc Natl Acad Sci U S A 103(38):14164-14169

Ishibashi JI, Wakita H, Nojiri Y, Grimaud D, Jeanbaptiste P, Gamo T, Auzende JM, Urabe T (1994a) Helium and carbon geochemistry of hydrothermal fluids from the north Fiji basin spreading ridge (southwest pacific). Earth Planet Sci Lett 128(3-4):183-197

Ishibashi J, Grimaud D, Nojiri Y, Auzende JM, Urabe T (1994b) Fluctuation of chemical-compositions of the phase-separated hydrothermal fluid from the North Fiji Basin Ridge. Mar Geol 116 $(1-2): 215-226$ 
Ishibashi J, Sano Y, Wakita H, Gamo T, Tsutsumi M, Sakai H (1995) Helium and carbon geochemistry of hydrothermal fluids from the mid-Okinawa trough back-arc basin, southwest of Japan. Chem Geol 123(1-4):1-15

Ishibashi J, Sato M, Sano Y, Wakita H, Gamo T, Shanks WC (2002) Helium and carbon gas geochemistry of pore fluids from the sediment-rich hydrothermal system in Escanaba Trough. Appl Geochem 17(11):1457-1466

Ishibachi J et al (2002b) Concentration of biologically important chemical species in hydrothermal fluids from submarine arc volcano suiyo seamount. Eos Trans AGU 83(47), Fall Meets. Suppl., Abstract \#V11C-05

Ishibashi J-I, Noguchi T, Toki T, Miyabe S, Yamagami S, Onishi Y, Yamanaka T, Yokoyama Y, Omori E, Takahashi Y, Hatada K, Nakaguchi Y, Yoshizaki M, Konno U, Shibuya T, Takai K, Inagaki F, Kawagucci S (2014) Diversity of fluid geochemistry affected by processes during fluid upwelling in active hydrothermal fields in the Izena Hole, the middle Okinawa Trough back-arc basin. Geochem J 48(3):357-369

Kawagucci S, Okamura K, Kiyota K, Tsunogai U, Sano Y, Tamaki K, Gamo T (2008) Methane, manganese, and helium-3 in newly discovered hydrothermal plumes over the Central Indian Ridge, $18^{\circ}$ $20^{\circ} \mathrm{S}$. Geochem Geophys Geosyst 9:Q10002. doi:10.1029/ 2008GC002082

Kawagucci S, Shirai K, Lan TF, Takahata N, Tsunogai U, Sano Y, Gamo T (2010a) Gas geochemical characteristics of hydrothermal plumes at the HAKUREI and JADE vent sites, the Izena Cauldron, Okinawa Trough. Geochem J 44(6):507-518

Kawagucci S, Toki T, Ishibashi J, Takai K, Ito M, Oomori T, Gamo T (2010b) Isotopic variation of molecular hydrogen in $20-375^{\circ} \mathrm{C}$ hydrothermal fluids as detected by a new analytical method. J Geophys Res Biogeosci 115, G03021. doi:10.1029/2009JG001203

Kawagucci S et al (2011) Hydrothermal fluid geochemistry at the Iheya North field in the mid-Okinawa Trough: implication for origin of methane in subseafloor fluid circulation systems. Geochem $\mathrm{J} 45$ (2):109-124

Kawagucci S et al (2013a) Geochemical origin of hydrothermal fluid methane in sediment-associated fields and its relevance to the geographical distribution of whole hydrothermal circulation. Chem Geol 339:213-225

Kawagucci S et al (2013b) Post-drilling changes in fluid discharge pattern, mineral deposition, and fluid chemistry in the Iheya North hydrothermal field, Okinawa Trough. Geochem Geophys Geosyst 14:4774-4790

Kishida K, Sohrin Y, Okamura K, Ishibachi J (2004) Tungsten enriched in submarine hydrothermal fluids. Earth Planet Sci Lett 222 $(3-4): 819-827$

Konno U, Tsunogai U, Nakagawa F, Nakaseama M, Ishibashi JI, Nunoura T, Nakamura KI (2006) Liquid $\mathrm{CO}_{2}$ venting on the seafloor: Yonaguni knoll IV hydrothermal system, Okinawa Trough. Geophys Res Lett 33:L16607

Kumagai $\mathrm{H}$ et al (2008) Geological background of the Kairei and Edmond hydrothermal fields along the Central Indian Ridge: implications of their vent fluids' distinct chemistry. Geofluids 8 (4):239-251

Lilley MD, Butterfield DA, Olson EJ, Lupton JE, Macko SA, Mcduff RE (1993) Anomalous $\mathrm{CH}_{4}$ and $\mathrm{NH}_{4}{ }^{+}$concentrations at an unsedimented mid-ocean-ridge hydrothermal system. Nature 364 (6432):45-47

Lilley MD, Butterfield DA, Lupton JE, Olson EJ (2003) Magmatic events can produce rapid changes in hydrothermal vent chemistry. Nature 422(6934):878-881

Lin LH, Slater GF, Lollar BS, Lacrampe-Couloume G, Onstott TC (2005) The yield and isotopic composition of radiolytic $\mathrm{H}-2$, a potential energy source for the deep subsurface biosphere. Geochim Cosmochim Acta 69(4):893-903

McCollom TM (2008) Observation, experimental, and theoretical constraints on carbon cycling in mid-ocean ridge hydrothermal systems. In: Lowell RP, Seewald JS, Metaxas A, Perfit MR (eds) Magma to microbe: modeling hydrothermal processes at ocean spreading centers. American Geophysical Union, Washington, DC, pp 193-213

McCollom TM (2013) Laboratory simulations of abiotic hydrocarbon formation in Earth's deep subsurface. Rev Min Geochem 75:467-494

McCollom TM, Seewald JS (2006) Carbon isotope composition of organic compounds produced by abiotic synthesis under hydrothermal conditions. Earth Planet Sci Lett 243(1-2):74-84

McCollom TM, Bach WG (2009) Thermodynamic constraints on hydrogen generation during serpentinization of ultramafic rocks. Geochim Cosmochim Acta 73(3):856-875

McCollom TM, Lollar BS, Lacrampe-Couloume G, Seewald JS (2010) The influence of carbon source on abiotic organic synthesis and carbon isotope fractionation under hydrothermal conditions. Geochim Cosmochim Acta 74(9):2717-2740

Merlivat L, Pineau F, Javoy M (1987) Hydrothermal vent waters at $13^{\circ} \mathrm{N}$ on the east pacific rise - isotopic composition and gas concentration. Earth Planet Sci Lett 84(1):100-108

Mottl MJ et al (2011) Chemistry of hot springs along the eastern Lau spreading center. Geochim Cosmochim Acta 75 (4):1013-1038

Nakagawa S, Takai K, Inagaki F, Chiba H, Ishibashi J, Kataoka S, Hirayama H, Nunoura T, Horikoshi K, Sako Y (2005) Variability in microbial community and venting chemistry in a sediment-hosted backarc hydrothermal system: Impacts of subseafloor phaseseparation. FEMS Microbiol Ecol 54(1):141-155

Nakai N, Yoshida N, Ando N (1974) Isotopic studies on oil and gas fields in Japan. Chikyu Kagaku 7:87-98 (in Japanese with English abstract)

Nakano A, Matsumura M, Ishibashi J (2001) Geochemistry of hydrothermal fluids from the Hatoma Knoll in the South Okinawa Trough. JAMSTEC J Deep Sea Res 18:139-144

Noguchi T, Shinjo R, Ito M, Takada J, Oomori T (2011) Barite geochemistry from hydrothermal chimneys of the Okinawa Trough: insight into chimney formation and fluid/sediment interaction. J Mineral Petrol Sci 106(1):26-35

Pearson A, Seewald JS, Eglinton TI (2005) Bacterial incorporation of relict carbon in the hydrothermal environment of Guaymas Basin. Geochim Cosmochim Acta 69(23):5477-5486

Proskurowski G, Lilley MD, Brown TA (2004) Isotopic evidence of magmatism and seawater bicarbonate removal at the endeavour hydrothermal system. Earth Planet Sci Lett 225(1-2):53-61

Proskurowski G, Lilley MD, Kelley DS, Olson EJ (2006) Low temperature volatile production at the Lost City Hydrothermal Field, evidence from a hydrogen stable isotope geothermometer. Chem Geol 229(4):331-343

Reeves EP, Seewald JS, Saccocia P, Bach W, Craddock PR, Shanks WC, Sylva SP, Walsh E, Pichler T, Rosner M (2011) Geochemistry of hydrothermal fluids from the PACMANUS, Northeast Pual and Vienna Woods hydrothermal fields, Manus Basin, Papua New Guinea. Geochim Cosmochim Acta 75(4):1088-1123

Reeves EP, Seewald JS, Sylva SP (2012) Hydrogen isotope exchange between n-alkanes and water under hydrothermal conditions. Geochim Cosmochim Acta 77:582-599

Saegusa S, Tsunogai U, Nakagawa F, Kaneko S (2006) Development of a multibottle gas-tight fluid sampler WHATS II for Japanese submersibles/ROVs. Geofluids 6(3):234-240

Sakai H, Gamo T, Kim ES, Tsutsumi M, Tanaka T, Ishibashi J, Wakita H, Yamano M, Oomori T (1990a) Venting of carbon-dioxide rich 
fluid and hydrate formation in mid-Okinawa Trough Backarc Basin. Science 248(4959):1093-1096

Sakai H et al (1990b) Unique chemistry of the hydrothermal solution in the mid-Okinawa Trough Backarc Basin. Geophys Res Lett 17 (12):2133-2136

Sano Y, Fischer TP (2013) The analysis and interpretation of noble gases in modern hydrothermal systems. In: Burnard P (ed) The noble gases as geochemical tracers, advances in isotope geochemistry. Springer, Berlin/Heidelberg, pp 249-317

Seewald JS, Seyfried WE (1990) The effect of temperature on metal mobility in subseafloor hydrothermal systems - constraints from basalt alteration experiments. Earth Planet Sci Lett 101 (2-4):388-403

Seewald JS, Seyfried WE, Shanks WC (1994) Variations in the chemical and stable-isotope composition of carbon and sulfur species during organic-rich sediment alteration - an experimental and theoretical-study of hydrothermal activity at Guaymas Basin, Gulf of California. Geochim Cosmochim Acta 58(22):5065-5082

Seyfried WE, Seewald JS, Berndt ME, Ding K, Foustoukos DI (2003) Chemistry of hydrothermal vent fluids from the main Endeavour field, northern Juan de Fuca Ridge: geochemical controls in the aftermath of June 1999 seismic events. J Geophys Res Solid Earth 108(B9):2429

Shinjo R, Kato Y (2000) Geochemical constraints on the origin of bimodal magmatism at the Okinawa Trough, an incipient backarc basin. Lithos 54:117-137

Sugimoto A, Wada E (1995) Hydrogen isotopic composition of bacterial methane $-\mathrm{CO}_{2} / \mathrm{H}_{2}$ reduction and acetate fermentation. Geochim Cosmochim Acta 59(7):1329-1337

Suzuki R, Ishibashi JI, Nakaseama M, Konno U, Tsunogai U, Gena K, Chiba H (2008) Diverse range of mineralization induced by phase separation of hydrothermal fluid: case study of the Yonaguni Knoll IV hydrothermal field in the Okinawa Trough back-arc basin. Res Geol 58(3):267-288

Takai K, Nakamura K, Toki T, Tsunogai U, Miyazaki M, Miyazaki J, Hirayama H, Nakagawa S, Nunoura T, Horikoshi K (2008) Cell proliferation at $122^{\circ} \mathrm{C}$ and isotopically heavy $\mathrm{CH}_{4}$ production by a hyperthermophilic methanogen under high-pressure cultivation. Proc Natl Acad Sci U S A 105(31):10949-10954

Tivey MK, Stakes DS, Cook TL, Hannington MD, Petersen S (1999) A model for growth of steep-sided vent structures on the Endeavour Segment of the Juan de Fuca Ridge: results of a petrologic and geochemical study. J Geophys Res Solid Earth 104 (B10):22859-22883

Toki T, Tsunogai U, Ishibashi J, Utsumi M, Gamo T (2008) Methane enrichment in low-temperature hydrothermal fluids from the Suiyo
Seamount in the Izu-Bonin Arc of the western Pacific Ocean. J Geophys Res Solid Earth 113:B08s13. doi:10.1029/ 2007jb005476

Tsuji T, Takai K, Oiwane H, Nakamura Y, Masaki Y, Kumagai H, Kinoshita M, Yamamoto F, Okano T, Kuramoto S (2012) Hydrothermal fluid flow system around the Iheya North Knoll in the midOkinawa trough based on seismic reflection data. J Volcanol Geoth Res 213:41-50

Tsunogai U, Ishibashi J, Wakita H, Gamo T, Watanabe K, Kajimura T, Kanayama S, Sakai H (1994) Peculiar features of Suiyo seamount hydrothermal fluids, Izu-Bonin arc - differences from subaerial volcanism. Earth Planet Sci Lett 126(4):289-301

Tsunogai U, Nakagawa F, Gamo T, Ishibashi J (2005) Stable isotopic compositions of methane and carbon monoxide in the Suiyo hydrothermal plume, Izu-Bonin arc: tracers for microbial consumption/ production. Earth Planet Sci Lett 237(3-4):326-340

Valentine DL, Chidthaisong A, Rice A, Reeburgh WS, Tyler SC (2004) Carbon and hydrogen isotope fractionation by moderately thermophilic methanogens. Geochim Cosmochim Acta 68 (7):1571-1590

Von Damm KL, Lilley MD (2004) Diffuse flow hydrothermal fluids from $9^{\circ} 50^{\prime} \mathrm{N}$ east pacific rise: origin, evolution and biogeochemical controls. In: Wilcock WSD, Delong EF, Kelley DS, Baross JA, Cary CS (eds) The subseafloor biosphere at mid-ocean ridges. AGU, Washington, DC, pp 245-268

Von Damm KL, Edmond JM, Measures CI, Grant B (1985) Chemistry of submarine hydrothermal solutions at Guaymas Basin, Gulf of California. Geochim Cosmochim Acta 49(11):2221-2237

Von Damm KL, Parker CM, Zierenberg RA, Lilley MD, Olson EJ, Clague DA, McClain JS (2005) The Escanaba Trough, Gorda ridge hydrothermal system: temporal stability and subseafloor complexity. Geochim Cosmochim Acta 69(21):4971-4984

Welhan JA, Lupton JE (1987) Light hydrocarbon gases in Guaymas Basin hydrothermal fluids: thermogenic versus abiogenic origin. Am Assoc Petrol Geol Bull 71:215-223

Whiticar MJ (1999) Carbon and hydrogen isotope systematics of bacterial formation and oxidation of methane. Chem Geol 161 (1-3):291-314

Yanagawa K et al (2013) Metabolically active microbial communities in marine sediment under high- $\mathrm{CO}_{2}$ and low-pH extremes. ISME $\mathrm{J} 7$ (3):555-567

You CF, Butterfield DA, Spivack AJ, Gieskes JM, Gamo T, Campbell AJ (1994) Boron and Halide systematics in submarine hydrothermal systems - effects of phase-separation and sedimentary contributions. Earth Planet Sci Lett 123(1-4):227-238 